WS1-1 Delayed surgery for acute severe ulcerative colitis is associated with increased risk of post-operative complications

Nuffield Department of Surgery ${ }^{1)}$, Colorectal Surgery Unit, John Radcliffe Hospital, Oxford ${ }^{2)}$, Dept of Cellular Pathology, John Radcliffe Hospital, Oxford ${ }^{3)}$, Gastroenterology Unit, John Radcliffe Hospital, Oxford $^{4}$

Baljit Singh ${ }^{1)}$, Jon Randall ${ }^{2)}$, Ippokratis Sarris ${ }^{2)}$, Bryan F Warren ${ }^{3)}$, Simon PL Travis ${ }^{4)}$, Neil Mortensen ${ }^{2)}$, Bruce George ${ }^{2)}$

Purpose The optimal timing for surgery in inflammatory bowel disease remains controversial. Recent evidence suggests the threshold for surgery may be too highl. This study aimed to assess whether the duration of medical therapy, prior to colectomy and ileostomy for acute severe ulcerative colitis(ASUC) was related to post-operative morbidity.

Methods All patients who underwent urgent colectomy and ileostomy for ASUC during a 5 year period were identified from a prospective database. Patient details, preoperative therapy, operative details and complications to last follow up were recorded. Results 80 patients ( 42 male, median age 37 years) were identified. All patients were treated pre-operatively with high dose intravenous steroids. 23 patients $(29 \%)$ received intravenous ciclosporin. There were 27 complications in 22 patients in the early post-operative period following subtotal colectomy and ileostomy formation. There was no early post-operative mortality. $85 \%$ of patients underwent further planned surgery including restorative ileo-anal pouch in $72 \%$. 48 patients (60\%) suffered at least one complication during the long-term follow-up period (median follow-up 5.4 years). Patients who suffered a major complication at any time during the follow-up period had a significantly longer duration of medical therapy prior to colectomy and ileostomy (median 8 days) compared to patients with no complications (median 5 days) [Mann-Whitney U, $\mathrm{p}=0.036]$.

Conclusions This study suggests that delayed surgery for patients with ASUC who do not respond to optimum medical therapy is associated with an increased risk of post-operative complications.

1. Roberts S, Williams J, Yeates D, Goldacre M. Mortality in patients with and without colectomy admitted to hospital for ulcerative colitis and Crohn's disease : record linkage studies. British Medical Journal 2007 ; 335 : 1033-6.

\section{WS1-2 潰瘍性大腸炎重症発症例の手術適応}

東北大学分子病態外科学 ${ }^{1)}$, 東北大学大学院医学系研究科消化器病態 学分野 ${ }^{22}$, 東北大学病院胃腸外科 ${ }^{3)}$, 東北大学大学院医学系研究科生体

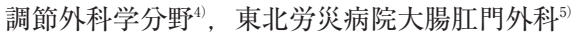

福島浩平 ${ }^{12}$, 木内喜孝 ${ }^{2)}$, 小川 仁3), 三浦 康 ${ }^{3)}$, 羽根田祥 ${ }^{4)}$,

佐々木嚴4), 高橋賢一 ${ }^{5}$, 舟山裕士 ${ }^{5}$

【はじめに】内科治療の選択肢が広がり, 潰瘍性大腸炎重症例の緩解導 入治療は着実に進歩しているように見える。手術の回避はとりあえず 患者にとって望ましいことではあるが, 緩解導入後の治療経過は必ず しも明らかではない。とくに再燃を繰り返す場合，外科治療の選択時 期, 外科治療との QOL の優劣は不明である. 今回, 当院消化器内科症 例について外科側の視点で検討することにより，手術の夕イミングの 適正化には何が必要かを検討した.【方法】1997 年〜2006 年末まで東北 大学病院消化器内科にて加療した潰瘍性大腸炎症例のうち, 重症発症 例で緩解導入し得た 48 例を対象とした. 平均発症年齢は 27.4 才, 全大 腸炎型 36 例，左側大腸炎型 12 例であった。再燃，手術を中心にその 後の経過について後ろ向きに検討した.「緩解」は排便回数 2 回/日以 下, 腹痛 - 粘血便の消失, 「再燃」は 4 週以降再度緩解導入療法を施行 した場合，と定義した.【結果】初回重症例の累積非手術率をみると 50 ヶ月でで $82 \%, 100$ ケ月で $62 \%$ であった。累積非再燃率をみると 50 ケ月で $22 \%, 100$ ケ月で $16 \%$ であったが初回発作のみも 3 例認められ た. 長期経過例 31 例を 50 ヶ月の時点でみると, 手術施行 7 例, 3 回以 上の再燃 8 例でありうち 5 例がその後に手術, 残りの 3 例もその後に 再燃していた. 一方, 50 ケ月の時点で再燃が 3 回未満の 16 症例は, そ の後の手術施行は 1 例のみ, 再燃も 5 例と少数あった。 また, 3 回以上 の再燃例では, プレドニゾロン総投与量は平均 $13000 \mathrm{mg}$ を超えてい た【考察】50ケ月で 3 回以上再燃を繰り返す症例は, その後の経過か らその時点での手術適応を考慮して良いと考えられる。本疾患を根治 し得ない現状では, 内科外科に限らず治療目標は腹部症状のコント ロールと排便機能温存により QOL を維持すること, また, 進行癌の合 併を予防することである。 上記の観点から QOL を重視した手術適応 の適正化には，内科外科にまたがる縦断的 QOL 調査が必要であると 思われる。

\section{WS1-3＼cjkstart潰瘍性大腸炎に対する手術適応と治療方針}

弘前大学消化器外科

坂本義之, 村田暁彦, 小山 基, 木村 寛, 太田 栄, 袴田健一

(目的)従来では潰瘍性大腸炎に対する手術は 2 期分割手術を原則とし てきたが, 内科的治療の発達や外科手技の進歩により, 現在では一期 的な回腸肛門管吻合（IACA）を基本術式としている。しかし，実際に は手術時期や術式選択に苦慮する症例も少なくない。今回, 臨床的背 景因子と手術術式・術後成績を明らかにして, 術後合併症の危険因子 を検討した. (対象) 当教室で 1998 年から 2008 年に外科治療を行った 82 例を対象とした. 1) 臨床的背景因子 (年齢, 性別, 病脳期間, 内科 的前治療, ステロイド (SH) 投与総量, 直前 $\mathrm{SH}$ 量) と手術因子 (緊 急/準緊急, 手術理由, $1 / 2 / 3$ 分割, IACA/回腸肛門吻合 (IAA), 再手 術の有無, 入院期間) の関連，2) 術後合併症の危険因子について解析 した. (結果) 1) 症例の内訳は男性 41 例, 女性 41 例で, 平均年齢は 39.3 歳. 病脳期間は平均 4.5 年で, 前治療は SASP/5ASA が $89 \%$, 血球除 去療法が $38 \%$, サイクロスポリン (CyA) が $10 \%, 6 \mathrm{MP}$ が $17 \%$, ア ザチオプリンが $5 \%$ に施行されていた. SH 総投与量は平均 $11.1 \mathrm{~g}$ で, 直前投与量は平均 $34.3 \mathrm{mg}$ であった。手術は緊急が 30 例, 待機や準緊 急が 52 例. 分割手術は 1 期 20 例, 2 期 49 例, 3 期 4 例であり, 再建 術式は IAA が 16 例， IACA が 57 例。前期（1998-2002 年）と比較す ると後期（2003-7 年）で血球除去療法・CyA・6MP の前治療例が多 く, SH 総投与量は減少していた。ささらに, 腸管穿孔や腹膜炎による緊 急手術が減少し，一期的手術が $40 \%$ と増加していた．2）術後合併症 は 39 例 $(48 \%)$ であり, 縫合不全が 6 例 $(7.3 \%)$, 創感染・創し開 5 例, 腹腔内膿瘍 5 例, 腸閉塞 9 例, 腸炎 6 例, 消化管穿孔 3 例, 回腸 襄炎 3 例, 残存直腸出血 2 例. 再手術は腸管穿孔などの 5 例 (6.1\%)で, 縫合不全は全例保存的に治癒が得られた. 術後合併症の危険因子とし て直前 SH 投与量, 緊急手術, IAA が有意な因子であった。(結語) 一 期的手術の適応についてはさらなる検討が必要であるが, 2 期分割と 比較して合併症に有意差は無く，入院期間も短く，患者の身体的・精 神的・社会的な負担は軽減されていた。 今後，一期的に安全な手術が 行えるように，内科的前治療と手術時期について内科とより綿密な連 携をはかる必要がある.

\section{WS1-4シクロスポリン投与が外科治療成績に及ぼす影響}

広島大学病態制御医科学外科

清水 亘, 大毛宏喜, 繁本憲文, 渡谷祐介, 兽我祐一郎, 島筒和史

【目的】シクロスポリンが重症例の緩解導入に用いられる症例では, 従 来と比較して手術の夕イミングが先延ばしになる傾向にある。本薬剤 の投与が術後合併症に及ぼす影響を検討した.【対象・方法】当施設に おいて 1985 年 10 月から 2009 年 5 月までに施行した潰瘍性大腸炎手 術症例 176 例中, 重症例に対する緊急手術を行った 50 症例を検討対象 とした．シクロスポリン投与の有無を含めた術前治療, 術前状態, 術 後合併症について比較した.【結果】術前にシクロスポリン持続静注療 法を施行していたのは 7 例 $(14 \%)$ で, 平均投与日数は 6.4 日であった. シクロスポリン投与前に, 全例でステロイド静脈投与が行われており, 投与量の中央值は $40 \mathrm{mg}(20-60 \mathrm{mg})$, 術前の Clinical Activity Index (CAI) は平均值 14.1 であった。 シクロスポリン非投与群 (43 例) でも, 術前の PSL 術前投与量の中央值は $40 \mathrm{mg}(0-80 \mathrm{mg})$ で, 術前 CAI は 13.9 と投与群と比較して重症度に差はなかった. 全症例に対して, 結腸 亜全摘を緊急に行った結果, 手術時間および出血量は両群間に有意差 は認めず，手術そのものに違いは見られなかった。次に術後合併症を 比較すると, 表層手術部位感染はシクロスポリン投与群で 3 例 (42.8\%), 非投与群で 13 例 (30.2\%) と, 両群間に有意差はなかった。 しかし腹腔内感染は投与群で 3 例 (42.8\%), 非投与群で 4 例 $(9.3 \%)$ と, シクロスポリン投与群で有意に $(\mathrm{p}=0.019)$ 高率であった. さらに術後 血流感染の発症率がそれぞれ $22.2 \%, 4.7 \%$ と, シクロスポリン投与群 では有意に高率であった $(\mathrm{p}=0.032)$. 長期的合併症としての腸閉塞は, 術後 1 年間の観察期間中それぞれ $42.8 \%, 27.9 \%$ と有意差はなかった. また両群とも手術死亡例はなかった.【結語】シクロスポリンで緩解導 入を試みる場合は, 本薬剤が術後早期の重篤な合併症発症率を上昇さ せることを念頭に置く必要がある. 病勢の強い重症例では「だめで 元々」ではなく, 投与しない選択肢も大切と考える. 


\section{WS1-5 重症潰痬性大腸炎緊急手術症例から検討した的確な外科治 療のタイミングについて}

浜松医科大学第二外科

倉地清隆, 中村光一, 深澤貴子, 澤柳智樹, 原田 岳, 中村利夫, 今野弘之

【はじめに】潰瘍性大腸炎に対する治療は, 白血球・顆粒球除去療法や 免疫抑制剂療法により, これまで手術適応と考えられてきた症例にお いても緩解導入が得られており, 最近 10 年間で大きく変貌している. 一方, 一時的に緩解導入を得ても再燃し, 最終的には全身状態が重篤 化して緊急手術となる症例も増えており，術後合併症や治療期間の延 長など結果として患者の QOL を損なっている.【目的】当院における 最近 10 年間の潰瘍性大腸炎緊急手術例を検討し, 重症例における的確 な手術のタイミングについて検討した.【対象】1998 年 12 月〜2009 年 4 月までの 10 年間の当院における潰瘍性大腸炎手術 65 症例中 7 例 (年齢：25-60 歳, 平均 39 歳, 男女比 $6: 1$ ) に緊急手術を施行した. 【結 果】緊急手術理由は出血性ショック 5 例が最多で, 全結腸壊死 1 例, 敗血症 2 例であった. 術前状況は全例術前に $30-80 \mathrm{mg} /$ 日の大量ステ ロイドを投与, 5 例に白血球・顆粒球除去療法を施行していた. 術前合 併症として CMV 感染 3 例, DIC2 例，重症血栓症 2 例であった。手術 は 5 例に結腸亜全摘直腸粘液瘦回腸人工肛門，ハルトマン手術回腸人 工肛門 1 例, 大腸全摘 IACA 回腸人工肛門 1 例を施行した. 術後合併 症は, 術死 1 例, SSI6 例 (腹腔内膿瘍 4 例), 残存直腸出血 3 例 (残存 直腸切除 IACA1 例, 保存的治療 2 例), 癒着性腸閉塞 2 例であった. 術後合併症率は非緊急手術症例に比べて高率に発生し, 平均在院期間 も延長していた【考察】緊急手術症例は，直前までの大量ステロイド 投与に加え出血性ショックを併発し, 全身状態不良から救命優先のた め低侵襲な三期手術を選択せざるをえない症例が多い。また術後 SSI は必発で, 敗血症や腹腔内膿瘍などの治療には極めて苦慮する。外科 治療に対する患者側の問題点も指摘されるが, 内科的治療不応例は, 早期の段階から外科医と内科医および患者間との密接な関係を取り, 症状が悪化した場合には, 過剩なステロイドパルス療法や白血球・顆 粒球除去療法で病状のコントロールを試みることなく, ショック状態 に陥る前に手術を考慮することが予後と QOL の改善重要である.

\section{WS1-6 就学期における難治性潰瘍性大腸炎の手術適応について}

奈良県立医科大学消化器総合外科 ${ }^{1}$, 奈良県立医科大学中央内視鏡超 音波部 ${ }^{2)}$, 健生会奈良大腸肛門病センター ${ }^{3)}$

中川 正 ${ }^{1}$ ，藤井久男 ${ }^{2)}$ ，小山文一 ${ }^{1)}$ ，内本和晃 ${ }^{1)}$, 大柣憲一 ${ }^{1)}$,

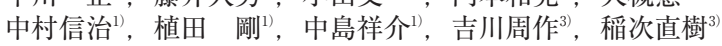

【背景】潰瘍性大腸炎は若年者に好発し，再燃緩解を繰り返して慢性に 経過する. とくに就学期の患者においては進学・就職といった人生の 大切な節目に病状の悪化が重なると進路変更を余儀なくされることが ある. 成長障害に関して難治例には手術適応を検討するよう喚起され てきたが, 現在の社会状況を考慮すると, 社会的適応の重要性が増し てきていると思われる.【目的】就学期に扔ける潰瘍性大腸炎手術自験 例の成績から, 就学における難治性潰瘍性大腸炎に対する手術適応に ついて検討する.【対象】 1990 年〜2008 年に奈良県立医科大学, 消化 器・総合外科, および土庫病院, 奈良大腸肛門病センターにおいて, 外科手術が行われた 99 例。内わけは, 25 歳未満の学生が 15 例 (15.2\%), 25 歳未満の社会人が 9 例 (9.1\%), 26 歳以上が 75 例 $(75.7 \%)$ であった、【結果】待機手術, 緊急手術の割合は, 緊急, 準緊急手術が 13 例 $(86.7 \%)$, 待機的根治術が 2 例 $(13.3 \%)$ であった。待機手術が 行われた 2 例はともに合併症を併発せず，休学を必要としなかった。 緊急，準緊急手術が行われた 13 例では 5 例（38.5\%）に合併症を認め たが，そのうちの 10 例に関しては，2期目の根治手術時には学業を考 慮して, 長期休㗇中に手術を行うことが可能であり, かつ休㗇中に退 院可能であった。残りの 3 例については, 病状の増悪や合併症により 長期休学を余儀なくされた。結果として，15 例中 12 例 (80\%) で学業 への支障を最小限にとどめることができた.【まとめ】 小児, 就学期の 難治性潰瘍性大腸炎患者にとって進学, 就職は大きなハードルである. 腹腔鏡下手術の選択や春休み, 夏休みなどに合わせた手術日設定など, 患者さんに負担の少ない治療計画を立てることにより，手術により難 治性を打開し，進学・就職をサポートできる可能性がある。小児, 就 学期における難治例においては進学, 就職を勘案して手術適応を検討 するよう喚起したい.

\section{WS1-7クローン病の手術適応とタイミング}

兵庫医科大学炎症性腸疾患センター ${ }^{1)}$, 兵庫医科大学下部消化管外 科 ${ }^{2)}$, 兵庫医科大学感染制御部 ${ }^{3)}$, 兵庫医科大学篠山病院 ${ }^{4}$

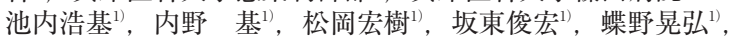
冨田尚裕 ${ }^{2}$, 竹末芳生 ${ }^{3)}$, 福田能啓 ${ }^{4)}$, 松本誉之 ${ }^{1}$

（目的）クローン病（以下 CD）に対する内科的治療法の進歩により 手術適応にどのような恋化があったのかを明らかにすることを目的と した. (対象) 2008 年 12 月までに手術を行った CD 症例 633 例を対象 とし, 手術適応は 2000 年以前に初回手術を行った 315 例と 2001 年以 降に初回手術を行った 318 例に分けて検討した. (結果) 1. 手術適応の 変遷 : 2000 年以前に初回手術を行った症例では非穿孔型 (狭窄, 出血, 癌） 150 例 $(47.6 \%)$, 穿孔型（㾇孔, 膿瘍, 穿孔） 129 例 $(41.0 \%)$, 肛 門病変 36 例 $(11.4 \%)$ であり，2001 年以降の症例では非穿孔型 153 例 $(48.1 \%)$, 穿孔型 126 例 $(39.6 \%)$, 肛門病変 39 例 $(12.3 \%)$ と両群 間に有意差は認めなかった。個別の手術適応では穿孔が 37 例 $(11.7 \%)$ から 16 例 $(5.0 \%)$ に有意に減少していた． 2. 当院での手術適応の変 遷 : 狭窄 ; バルーン拡張術導入以前は TPN 後, エレンタール増量中 に再度腸閉塞症状を生じる症例に関しては手術としていたが，現在で は，まずバルーン拡張術を行っている。瘦孔；内㾇症例に関しては以 前と同様にまず手術を選択している. 内瘦部の発癌症例は 3 例経験し ているがいずれも進行癌である。膿瘍；以前よりドレナージ後の手術 を基本としている. 出血：レミケードの導入後変化しており，1日 4 単位程度の輸血を要する出血であれば，まずレミケードを投与するこ とにしている. それ以上の出血症例に関してはまずIVR を試みている が，手術となった症例も存在する. 3. 直腸・肛門病変の悪化と直腸切 断術の適応：直腸肛門病変の悪化のために人工肛門造設術を行った症 例が 124 例あり，この内, 閉鎖術を行い, 2 年以上 stomaなしで経過観 察している症例はわずか 1 例で $99 \%$ の症例が永久人工肛門であった. また, 直腸肛門病変部の発癌症例 8 例中 5 例はすでに死亡しており予 後は不良であった. (結語) 腸管病変に対する手術適応は狭窄と出血で 今後変化していくものと思われた。 また, 直腸肛門病変の悪化症例に 対しては現在よりも早期に直腸切断術を選択しても良いのではないか と思われた。

\section{WS1-8 当科におけるクローン病の外科的手術の適応とそのタイミング}

藤田保健衛生大学下部消化管外科 ${ }^{12}$, 藤田保健衛生大学消化器内科 ${ }^{2)}$ 花井恒一 ${ }^{1)}$, 前田耕太郎 ${ }^{1)}$, 佐藤美信 ${ }^{12}$, 小出欣和 ${ }^{12}$, 松岡 宏 ${ }^{1)}$, 勝野秀稔 ${ }^{1)}$, 野呂智仁 ${ }^{1)}$, 安形俊久 ${ }^{1)}$, 本多克行 ${ }^{1)}$, 塩田規帆 ${ }^{1)}$, 尾関伸司 ${ }^{1)}$, 平田一郎 ${ }^{2}$

【はじめに】クローン病は若年者に多く，社会的な背景の考慮や再手術の 確率が高いこと, 病変の複雑なことが多いことから手術適応やその夕イ ミングを決定するのが難しいのが現状である，近年，内科的治療では薬 剂, IVR, 内視鏡的拡張術などの進歩や外科的治療では, 狭窄形成術の応 用や腹腔鏡手術の採用により手術の適応の夕イミング時期が変化してき ている. そこで, 現在の当科に扔けるクローン病手術の適応と夕イミング について報告する. (手術適応】 A. 待機手術 1) 狭窄 2) 瘦孔 3) 繰り返す 出血 4）悪性化 B. 準緊急, 緊急手術 1）穿孔 2）中毒性巨大結腸症 3）大 量出血 4) 膿瘍 5) イレウスなどとしている. 【手術のタイミングに対する 工夫】待機手術例は基本的に栄養状態を良くしてから手術を行っている. 緊急性のある症例は，病変を最小限の処置に留めることや術前全身状態 を安定させ術中術後の合併症を減少させること, さらに腹腔鏡手術を可 能にさせる目的で以下の工夫を行っている，1）大量出血, 膿瘍形成例 : 不安定な全身状態下での手術は, 必要以上の腸管切除や病変の取り残す 可能性が高くなる。 そのため, IVRを施行し可能な限り緊急手術を避け, 病変部を再検索した後，手術を施行している。2) 高度狭窄例：狭窄部よ り口側腸管の浮腫は, 腸管切除範囲を広くする。 そのためイレウスチュー ブで減圧しながら術前栄養状態を確保する. 3) 内視鏡的拡張が可能な病 変では, 内視鏡的拡張術を行う【結果】2009 年 3 月までに当科で施行した クローン病手術は, 156 例. 231 手術 (以下数字は手術数) 腹腔鏡下 54 , 開 腹 177\}で，その中でIVR 施行例 8, イレウスチューブでの減圧処置 14 を行った. 術前処置により腹腔鏡下手術で行えた症例は 6 であった. 適応 (重複を含む)：待機; 狭窄 187 , 瘦孔 78 , 癌 2 , 外瘦 17 . 準緊急; 膿瘍 29 (IVR 後 5 例), 繰り返す出血 11 (IVR3), ILEUS 12 緊急; 穿孔 9 (拡張 術による 3$)$, 大量出血 2 であった. 主な術中術後合併症; 縫合不全 7 , 腹 腔内膿瘍 4, 出血 2 , (うち IVR 後 0)【結語】緊急性のあるクローン病手術 症例では, IVR, 術前処置の工夫により縮小手術を可能とし長期的な予後 の改善が期待できる.内視鏡拡張術においては慎重に行うことが重要で あると考えられた。 
WS1-9 外科治療を行ったクローン病症例の特徴と手術適応および タイミング

社会保険中央総合病院大腸肛門病センター 西尾梨沙，法地聡果，金子由紀，高橋 聡，小野朋二郎，黒木ゆり， 森本幸治, 岡田大介, 古川聡美, 岡本欣也, 山名哲郎, 佐原力三郎

目的：近年クローン病に対する内科治療は infliximab などの新しい治 療法が加わり, 入院・手術率の減少が期待されているが, 狭窄, 瘦孔, 穿孔など多彩な病態により内科治療の範囲を超え外科治療の適応とな ることが多い. 今回, 外科治療を行った症例を分析し, その特徵と手 術適応，タイミング等について検討した。対象・方法：2008 年 1 月か ら 2008 年 12 月に開腹あるいは腹腔鏡手術を受けたクローン病症例 139 例について, 手術適応, 術前治療, 手術時期などを retrospective に検討した，結果：手術適応は，狭窄 32\%(44/139 例), 瘦孔 $23 \%$ (32 例), 狭窄 +㾇孔 $28 \%$ (39 例), 膿瘍 6\% (9 例), 穿孔 6\% (8 例), 難治性痔瘦 3\%（4例）だった。術前治療は，ステロイド投与 $9 \%$ （13 例)，免疫抑制剂投与 $22 \%$ (30 例)， infliximab 投与 $15 \%$ (21 例)，栄 養療法 46\% (64 例) で, 狭窄, 瘦孔, 狭窄 +㾇孔群で有意差はなかっ た．発症から手術までの期間は全体で平均 11.8 年, 狭窄群 10.2 年, 瘦 孔群 13.5 年, 狭窄 +瘦孔群 12.7 年だった。手術回数は, 初回 $40 \%$ (55 例), 2 回目 $27 \%$ (38 例), 3 回目 17\% (24 例), 4 回目以上 $16 \%(22$ 例）であり，手術時間および術中出血量は $1 \cdot 2$ 回目の手術では平均 142 分, $271 \mathrm{~g}, 3$ 回目以降の手術では 180 分, 537g, また狭窄群の手術 時間および出血量は 241 分, $126 \mathrm{~g}$, 瘦孔群では 576 分, $201 \mathrm{~g}$ であり, 手術回数が多い, あるいは瘦孔症例では手術時間は長く, 出血量は多 い傾向がみられた。術後経過に関しては全体で 84\%（117/139 例）が 経過良好で, 吻合不全 $6 \%$ (8 例), 術後イレゥス $4 \%$ (5 例), 腹腔内 膿瘍 $1 \%$ (2 例) を認め, 狭窄, 㾇孔, 狭窄 + 婁㾞孔各群で差はなかっ たが, infliximab 投与群では吻合不全 $(19 \%, 4 / 21$ 例)が多かった $(\mathrm{p}=$ 0.02). 結論：口側腸管の拡張を伴う線維性狭窄では経口摂取に障害が でた時点で手術適応となる。一方，瘦孔症例では病変部腸管周囲の炎 症のため手術操作が煩雑であり, 内科治療に抵抗性のものは炎症が周 囲に波及しないうちに外科治療への切り替えが望ましいと考えられ た. なお, 今回の検討では infliximab 投与群で術後吻合不全の発生率が 高かったが, 症例数も少なく今後更なる検討が必要と考えられた.

WS1-10 クローン病腸管病変における待機手術タイミングの検討

三重大学消化管小児外科

吉山繁幸, 三木誓雄, 荒木俊光, 大北喜基, 藤川裕之, 安田裕美, 小池勇樹, 松下航平, 大竹耕平, 井上幹大, 内田恵一, 楠 正人

【目的】クローン病腸管病変に対する手術適応については, 出血, 穿孔, 中毒性巨大結腸症など緊急手術と, 狭窄, 難治性㾇孔, 膿瘍などの待 機手術に分類される。緊急手術例に対する手術タイミングについては 議論の余地がないが, 待機手術に関しては最善の手術タイミングは明 らかではない. 病変が進行し複雑化した症例では外科治療に揖いても 難渋する。. 今回クローン病腸管病変に対する適切な手術夕イミングに ついて. 術後合併症の観点より検討を行ったので報告する.【方法】2000 年 10 月より狭窄症状を主訴に当科にて手術を行ったクローン病腸管 病変 38 症例, 41 手術例を対象とした. 年齢, 術前栄養状態, 術前栄養 摂取法, 腸管病変, 手術時間, 出血量等患者背景と, 術後合併症 (surgical site infection : SSI）との関連を検討した.【結果】当科におけるク ローン病術後の SSI 発生率は全体で $29.2 \%$ であった. SSI の有無に関 して, 病型では大腸型の頻度が有意に高く, 内瘦の有無, 腹腔内膿瘍 の有無, 術前栄養摂取法, 手術時間, 出血量に有意差が認められた。 術前栄養摂取法では栄養の維持に経静脈栄養を必要とした症例で有意 にSSI の頻度が高かった.術前の栄養摂取法について検討を行なうと, 栄養状態の維持に経静脈栄養を必要とした症例では必要としなかった 症例に比べ, 内瘦, 腹腔内膿瘍の頻度が有意に高く, BMI は有意に低 值であった．多変量解析では経静脈栄養の有無が独立したSSI のリス ク因子であった、結論】今回の検討において, SSI の発生は病変が進行 した症例に多く認められた。病変の進行に平行して, 徐々に経口から $\mathrm{ED}, \mathrm{IVH}$ へと栄養摂取状況が変化し, 手術夕イミングを図る上で一つ の指標となりうる可能性が示唆された。術後の再発のリスク因子とし て術後合併症, 腹腔内膿瘍が報告されており, 術後の SSI 発生は, そ の治療にかかる医療コストのみならず患者の予後を規定する。栄養状 態の維持に経静脈栄養の補助を要する前に手術を検討する必要がある 可能性が示唆され, このタイミングでの消化器内科医と IBD 専門の外 科医との連携が重要であると考えられた.
WS1-11 Crohn 病の小腸狭窄に対するダブルバルーン小腸内視鏡 （DBE）を用いた内視鏡的バルーン拡張術（EBD）による手 術回避

福岡大学筑紫病院消化器科

別府孝浩, 松井敏幸, 平井郁仁

【目的】小腸の炎症性腸疾患では腸管狭窄が問題で, 外科的手術は再 発・再狭窄を考虑し可能な限り回避する事が望ましい。今回我々は Crohn 病小腸狭窄に対する EBD の有用性と手術回避率を明らかにす ることを目的とした.【対象と方法】2003 年から 2009 年に当科にて DBE を用いて EBD を施行した狭窄症状のある Crohn 病患者 44 症例 を対象とした，EBD 手技：FTS 社製の処置用 DBE，拡張バルーンは Boston 社 TTS balloon 使用. 男女比 $=34: 10$ 初回 EBD 時年齢 35 歳, 初回 EBD からの観察期間 16.7 ヶ月。病型は小腸型 30 例小腸大腸 型 14 例. IFX を併用した症例が 14 例. 計 101 回 EBD 施行.【成績】1. 短期成功率 (Scope が口側に挿入可能または症状が改善したものと定 義）は, 施行回数で $77 / 101: 76.2 \%$ 症例数で $32 / 44: 72.7 \%$. 非成功の 原因は, ファイバー挿入困難 7 例, 深い潰瘍 6 例, バルーン挿入不可 4 例, ガイドワーヤー扱入不可 2 例, 㿉孔形成 2 例, 長い狭窄 1 例で あった. 2. 手術例と非手術例の比較検討では, 病変の部位や狭窄数, 口側腸管の拡張の有無, IFX 併用の有無, 腹部手術歴の有無で手術移 行率に有意差なく狭窄長が $3 \mathrm{~cm}$ 以上で有意に手術となる症例が多い. $(\mathrm{P}=0.00076) 3$. 累積手術回避率は 1 年後, 2 年後 $75.4 \%, 3$ 年後 $60.0 \%$ であった。手術となった 12 例のうち 10 例が $\mathrm{EBD}$ 後 1 年以内に手術 となった。 4. 内科治療を要する合併症は症例数で $2 / 44: 4.5 \%$ 回数で 3/101:3.0\%. 急性膵炎 3 回で全例保存的に改善した. 穿孔例はなかっ た【結論】以上より DBE が到達可能な小腸狭窄のうち比較的短く深 い潰瘍のないものは EBD 可能であった。 その長期経過も良好である ため, Crohn 病の小腸狭窄例の一部は内視鏡治療により手術回避が可 能と考えられた。

WS1-12 クローン病狭窄病変に対するステロイド（SH）併用 Infliximab (IFX) に関する再考

弘前大学光学医療診療部 ${ }^{1)}$, 弘前大学 ${ }^{21}$

石黒 陽 ${ }^{1)}$, 櫻庭裕丈 ${ }^{2)}$, 花畑憲洋 ${ }^{2)}$, 吉村徹郎 ${ }^{2)}$, 佐々木賀広 ${ }^{2)}$, 福田眞作 ${ }^{1,2)}$

【目的，背景】クローン病の急性期にステロイドは有効であるが, 狭窄 を来たした場合，SHによる長期的効果は期待できず，また，IFX の狭 窄に対する改善効果についての詳細は明らかでない. IFX と SH 以外 の既存治療で狭窄を有する症例にする IFX 単独および SH 併用 IFX の効果を比較した.【方法】既存の治療 (ED. 5ASA Immunomodulator) で再燃時 (急性期) 狭窄が認められた症例で, Infliximab (IFX) (5mg/ $\mathrm{kg} \mathrm{0,2,6}$ 週投与後, $5 \mathrm{mg} / \mathrm{kg} 8$ 週毎) 単独 $(\mathrm{n}=8)$ もしくは SH $30 \mathrm{mg} /$ 日併用下 (2 週間以降漸減)に IFX $(n=9)$ を投与した。 バリウム二重 造影にて狭窄を評価した. Follow-up period は 12 1 月 (3-18 カ月)で ある. 万う孔症例, 既存のイレウス症例は除外した.【成績】狭窄例に 対し， 2 群間で SH 併用例と非併用例で比較した. SH 併用群 9 例で $6.27 \mathrm{~mm} \pm 1.25 \mathrm{~mm}(4-8 \mathrm{~mm})$ から $10.33 \mathrm{~mm} \pm 0.44 \mathrm{~mm}$ と有意な改善 $(\mathrm{p}<$ 0.01）をみた。また，狭窄部位の長軸方向の短縮も見られた，CDAI は $313 \pm 38$ から $131 \pm 13$ と有意な改善をみた $(\mathrm{p}<0.01)$. SH 非投与群 では $7.00 \mathrm{~mm} \pm 1.02 \mathrm{~mm}(3-11 \mathrm{~mm})$ から $5.87 \mathrm{~mm} \pm 0.63 \mathrm{~mm}$ と狭窄の有 意な改善なく (N.S.) むしろ悪化傾向, CDAI も $255 \pm 25$ から $266 \pm 23$ (N.S.) と改善なく, 2 例は閉塞症状のため手術となった. 合併症はいず れの群でも認められなかった.【結論】SH 併用 IFX の狭窄に対する改 善効果, 安全性が示唆された. 急性期において SH には IFX 単独投与 以外の機序が介在し, 改善する可能性がある. SH 依存は避けるべきで あるが, IFXによる維持効果を考慮し, 外科治療や拡張術以外に, 急 性期の狭窄を改善する目的で試みてよい治療と考えられた。 
WS1-13 クローン病に合併した大腸癌に対する手術タイミング

東京大学医科学研究所外科

篠㠃 大，畑 啓介，釣田義一郎

[背景と目的] クローン病 $(\mathrm{CD})$ では近年, 癌合併例の報告が急激に増 加しているが, 1 施設の症例数は限られており, その実態はまだ明らか になっているとは言い難い。 今回我々は CD に合併した大腸癌報告例 から内視鏡生検が術前診断の中心となることが予想される症例を選 び，それらの手術タイミングに関係する臨床病理学的特徴を明らかに することを目的として検討を行った. [対象と方法] 2008 年 6 月までに 医中誌に登録された発表のうち,クローン病/癌をキーワードに検索さ れた結果から大腸癌の症例は 120 例であった。痔㾞癌・肛門管癌など では直視下の組織検査が内視鏡的生検より有用であることが想定され るので除外すると 72 例が残り,これを検討対象とした。 これらには腫 瘍発見を目的としたサーベイランスで発見された症例は含まれていな い. [結果] 癌診断年齢は 25-89（中央值が 46.5）歳，男女比は $43: 24$ であった．罹病期間は-4-37（中央值が 6) 年で， 1 年未満が $27 / 71$ (38\%) と多かった. CD 診断時の年齢は 12-84(中央値が 36.5)歳であっ た．生検で診断がついたものは 63 例中 52 例（83\%）であったが, 術 後に判明したものが 6 例 $(11 \%)$, 剖検で確認されたものが 4 例 $(6 \%)$ と無視できない比率であった，癌の部位では盲腸・虫垂が 4 , 上行結腸 が 10 , 横行結腸が 7 , 下行結腸が $1, \mathrm{~S}$ 状結腸が 14 , 直腸が 33 と左側優 位であり欧米の分布とは大きく異なっていた。多重癌が 2 例認められ た. Dysplasiaの有無の記載は報告が少なかったが, ありとしたものが 7 例, なしが 10 例であった。癌の進行度では stage1 が 6 例, 2 が 19 例， 3 が 9 例， 4 が 11 例となっていた。 しかし予後は判明した 37 例中 16 例が死亡, うち少なくとも 11 例が 1 年以内であった. Stage と予後 が共に判明した 29 例では stage 1 で 5 例中 1 例が死亡, stage 2 で 10 例中 3 例死亡, 1 例が局所再発, stage 3 で 7 例中 3 例が死亡, 1 例が遠 隔転移ありとなっており, 症例数は少ないながら一般の大腸癌よりも 予後不良であることが示唆された. [結論]CD に合併した大腸癌では, 何らかの症状が出現してからの癌診断では治療を開始する夕イミング としては遅い．何らかの介入などの対策が必要と考えられる.

WS2-1 クローン病におけるインフレキシマブの効果および経過に関 する検討

大腸肚門病センター高野病院外科

緒方俊二, 山田一隆, 佐伯泰飷, 福永光子, 高野正太, 田中正文, 坂田玄太郎, 眞方紳一郎, 中村 寧, 久野三朗, 大湾朝尚, 野崎良一, 高野正博

【目的】クローン病の腸管病変と肛門病変に㧍けるインフレキシマブ (以 下 IFX)の効果および経過を検討すること.【対象と方法】 2002 年〜2009 年において IFX を使用したクローン病患者 71 例を対象とした. (1) 投 与法の違いによる効果の差, (2) 維持投与の効果・再発, (3) 投与後の手 術症例, (4) 栄養療法や免疫調整剂との併用効果等を検討した.【結果】男 女比は $55: 16$, 平均年齢 30 歳, 平均病悩期間が 8.5 年であった. IFX の投 与回数の中央值は 7 回, 観察期間の中央值は 13 ヶ月であった. 71 例中 44 例 $(62 \%)$ に肛門病変の合併を認めた．IFX 投与前に手術歴を有する 症例が 50 例 (開腹 28 例, 肛門 24 例, 重複あり) であった。副作用はア レルギー 8 例, 肺炎 1 例であった. (1) 3 種類の投与法別(導入 3 回のみ, エピソディック，計画的維持投与)の有効例は $1 / 6(17 \%), 4 / 5(80 \%)$, 58/60（97\%）と計画的維持投与で良好であった。また再手術率でも $3 /$ $6(50 \%) ， 3 / 5(60 \%) ， 5 / 60(8 \%)$ と維持投与で良好であった (2) 計 画的維持投与を行なった 60 例において, 腸管皮膚瘦 11 例中 9 例 $(82 \%)$ に閉鎖がみられた。腸管腔瘦を 2 例認めたが，閉鎖には至っていなかっ た. 腸管㾇 2 例においては 2 例とも腹腔内膿瘍をきたし手術となった. また，IFX 投与直前に肛門手術 (seton)を行なったものが 7 例あったが, 全例で改善した. (3) 計画的維持投与を行なった 60 例中, 病状悪化によ り手術を行なった例は 4 例（開腹手術 3 例，肛門手術 1 例）であった。 1 例は絞扼性イレウスでの緊急手術であった４例中 3 例は IFX 投与前 に腸管狭窄の治療歴があった. (4) IFX の併用療法としては, ED 療法を 行なったもの 45 例であったが, 再手術率は $\mathrm{ED}$ 療法ありで $13.3 \%, \mathrm{ED}$ 療法なしで $19.2 \%$ と有意差はなかった $(\mathrm{p}=0.51)$. 免疫調整剤を併用し たのもが 24 例であったが, 再手術率は免疫調整椷ありで $16.7 \%$, 免疫調 整剂なしで $14.9 \%$ と，これも有意差はなかった $(\mathrm{p}=0.85)$.【結語】IFX の計画的維持投与は有効であり, 再手術率も低かった。腸管皮膚瘦, 肚 門周囲膿瘍には有効であるが, 腸管瘦, 腸管腔瘦への効果は明らかでは なかった. $\mathrm{ED}$ 療法, 免疫調整剤との併用では再手術率に差はなかった.

\section{WS2-2クローン病に対する Infliximab の長期治療成績}

福岡大学筑紫病院消化器科

小野陽一郎，平井郁仁，松井敏幸

【目的】近年，抗 TNF- $\alpha$ 抗体である Infliximab (IFX) は，クローン病 (以下, CD) に対して寛解導入および寛解維持を目的として広く用いら れている。 しかし，長期の治療成績や治療効果に関する要因について は未だ不明な点も多い。 今回, IFX の長期治療成績と併用療法が効果 に関与するか否かを明らかにすることを目的とした.【方法】 2009 年 3 月までに当科で IFX を投与した CD 患者は, 191 例であり，このうち 151 例が計画的維持投与を受けていた.これら 151 例中, 長期経過の解 析が可能であった 137 例を対象とした。治療効果の判定は, 良好群： 追加治療をせず，通常の生活を送れている者，中間群：外科治療以外 の追加治療を要すも, 社会生活を送れている者, 不良群 : 外科的治療. 長期入院を要した者と定義し, 良好・中間群を有効, 不良群を無効と した．対象の経年的な治療効果を判定し，有効例と無効例について， 併用療法の有無, 内容などについて比較検討した.【成績】IFX 投与 1, 2,4 年後の有効率はそれぞれ $89.4 \%, 86.0 \% ， 76.5 \%$ であった. 2 年以 上投与された 43 例は, 開始 2 年後に良好群 22 例, 中間群 15 例, 不良 群 6 例と判定された, この 43 例で併用療法である在宅経腸栄養 (HEN : 900kcal 以上), アザチオプリン (AZA) の有無別に治療成績お よび IFX 投与前後の CRP 值を検討した. HEN 群 $(n=14)$ と非 HEN 群 $(\mathrm{n}=29)$ の治療成績は，それぞれ $85.7 \%, 86.2 \%$ が有効で有意差は みられなかった。しかし, IFX 導入前, 2 年後の CRP 值は, 非 HEN 群では, $1.3 \pm 1.5 \mathrm{mg} / \mathrm{dl}$ から $1.4 \pm 1.8$ であったのに対し, HEN 群では $1.1 \pm 1.1$ から $0.2 \pm 0.2$ と有意に改善率が高かった $(\mathrm{p}=0.00008)$. AZA 群 $(\mathrm{n}=23)$ と非 AZA 群 $(\mathrm{n}=20)$ では, 治療成績, 治療前後の CRP 值ともに有意な差は認めなかった.【結論】IFX の計画的維持投与は長 期的にも有効であった。また，HENの併用で，より炎症を鎮静化させ うることが示唆された. 今後, 粘膜治癒や㾇孔症例についても検討を 加える予定である。

\section{WS2-3 クローン病 Infliximab 維持投与例に対する Elemental diet の 必要性に関する検討}

藤田保健衛生大学消化管内科

長坂光夫, 平田一郎

【目的】これまでわが国のクローン病治療の中心は ED であったが近年 IFX の普及で欧米型の薬物療法中心の治療へと移行した。当科におけ るクローン病 IFX 維持療法中の症例の中で ED が有効といわれる小 腸型と有効性がそしい大腸型について ED 併用と臨床効果 (CRP と Alb）を検討した.【対象, 結果】 2008 年 6 月までに当科で IFX を投与 した症例 147 例. 内訳男性 115 例, 女性 32 例, 平均年齢 33.1 歳 (1274 歳) 初回投与時平均年齢 31.0 歳, 罹患期間平均 9.8 年 (0.2-24 年) 初 回投与時罹患期間 7.2 年, 総投与回数 1041 回, 平均投与回数 6.1 回 (134 回). そのうち小腸型 9 例, 平均年齢 31.6 歳 (17-39), 平均罹病期間 8.9 年 $(1-19)$, 平均 IFX 投与回数 6.6 回 $(1-20)$ であった。 そのうち IFX3 回以上維持投与中の 7 例, 平均年齢 $32.7(17-39)$, 平均罹病期 間 10.2 年 $(1-19)$, IFX 平均投与回数 8.2 回 $(3-20)$ で AZA の併用 3 例であった。 ED 併用は ED0p/日 1 例, $1 \mathrm{p} /$ 日 0 例, $2 \mathrm{p} /$ 日 2 例, $3 \mathrm{p} /$ 日 3 例, $4 \mathrm{p} /$ 日 0 例, $5 \mathrm{p} /$ 日 1 例で ED2p 以下/日の群と ED 3p 以上/日 の群を比較すると IFX の平均投与回数は 9.6 回 (4-20), 7.2 回 (3-4) で $\mathrm{AZA}$ 併用は 1 例と 2 例. 現状の CRP 值の平均值は 0.3, 0.42, と ED3p/ 以上の群がやや高值で平均 $\mathrm{Alb}$ 值は 4.5, 4.0 と $\mathrm{ED} 2 \mathrm{p} /$ 日以下の群がや や高值であった. 大腸型に関しては全体で 26 例, 平均年齢 35.9 歳 (15$73)$, 平均罹病期間 10.9 年 $(1-26)$, 平均 IFX 投与回数 6.5 回 $(1-23)$ であった. そのうち IFX3 回以上で維持投与中の症例は 9 例, 平均年齢 $39.2(20-73)$, 平均罹病期間 10.6 年 $(1-17)$, IFX の平均投与回数 13.3 回 $(3-23)$ でアザチオプリン（AZA）の併用 3 例であった. ED 併用 は ED0p/日 3 例, $1 \mathrm{p} /$ 日 1 例, $2 \mathrm{p} /$ 日 1 例, $3 \mathrm{p} /$ 日 4 例で ED $2 \mathrm{p}$ 以下/日 の群と ED3p 以上/日の群を比較すると IFX の平均投与回数はそれぞ れ 14.4 回 (3-23), 12.0 回 (10-14) でAZA 併用はそれぞれ 1 例と 2 例. 現状の CRP 值の平均值はそれぞれ 0.36, 1.12, と ED3p/以上の群で やや高值で平均 Alb 值はそれぞれ 4.42, 3.97 と ED2p/日以下の群でや や高值であったＩFX 寛解維持投与中の症例では ED の有無あるいは 1 日摂取量は小腸型と大腸型で有意な差はなく $\mathrm{ED}$ の増量で炎症反応 と栄養状態の改善は認められなかった。 
WS2-4 インフリキシマブによる寛解維持療法中のクローン病患者 に対する経腸栄養療法の再燃抑制効果：A Prospective Pilot Trial

四日市社会保険病院外科大腸肛門病 IBD センター 山本隆行, 梅枝 覚, 松本好市

【目的】最近，私どもはクローン病における経腸栄養療法の寛解維持効 果を検討した臨床試験の Systematic review を行い, エビデンスレベ ルは高くないが経腸栄養剤に寛解維持効果があることを報告してき た.しかし, Review された多くの臨床試験はインフリキシマブなどの 生物学的製剂が使用される以前に行われたものである。したがって, 生物学的製剂による寛解維持療法中の患者に対する経腸栄養療法の有 用性はこれまで報告されていなかった. 今回, 私どもはインフリキシ マブによる寛解維持療法中のクローン病患者において, 経腸栄養療法 の併用により臨床的再燃率を下げることができるか否かを Prospective に検証した.【方法】活動期クローン病に対してレミケードによる 寛解導入療法 $(5 \mathrm{mg} / \mathrm{kg}$ x3 [0,2,6 週]) で寬解（Crohn's disease activity index [CDAI ] score＜150）に至った症例で，レミケードによる寛 解維持療法 $(5 \mathrm{mg} / \mathrm{kg}, 8$ 週毎) が予定されている患者 40 人を対象とし た. 試験前に患者の経腸栄養療法に対するコンプライアンスを評価し, 良好な 24 例を経腸栄養療法群 (EN 群) に，不良 16 例を非経腸栄養療 法群（Non-EN 群）に振り分けた。EN 群では，夜間に成分栄養剤（エ レンタール)を 1200-1500mL 経鼻チューブより注入し，昼間は低脂肪 食（20-30g/day）を摂取した，Non-EN 群では，栄養剤を使用せず， 食事制限も行わなかった。上記のプロトコールで 56 週間治療を行い, CDAI score を定期的に評価した。臨床的再燃は CDAI score $\geqq 150$ と 定義した.【成績】両群間の臨床背景（年齢, 性, 病悩期間, 喫煙歴, 手術歴や病変部位）に有意差を認めなかった。 56 週間の観察期間中, 両群間の平均 CDAI score に有意差を認めなかった. EN 群の 5 人が経 過が良好なため, 栄養療法を中止した. 56 週間の観察期間中, EN 群で は 19 人 $(79 \%)$ が寛解を維持し, non-EN 群では 11 人 $(69 \%)$ が寛解 を維持したが, ITT 分析で両群間で寬解維持率に有意差を認めなかっ た【結論】インフリキシマブによる寛解維持療法中の患者において, 経腸栄養療法の併用は臨床的再燃率を有意に減少させなかった.

\section{WS2-5 Infliximab 計画的維持投与における免疫抑制剂併用の効果一 成分栄養療法併用の有無も含めて一}

札幌医科大学第一内科 ${ }^{1)}$, 札幌厚生病院 ${ }^{2)}$

渡邊秀平 ${ }^{1)}$, 本谷 聡 $^{2)}$, 今村哲理 ${ }^{2}$

【目的】以前我々は, IFX 計画的維持投与において治療開始時に免疫抑 制剤を併用した場合, 併用しない場合に比べ, IFXの無効・副作用に よる IFX 治療中止率が大幅に減少する事を報告した，そこで，当院で 新たに導入された症例も含めて, 免疫抑制剂併用の有無で分け, 緩解 維持率, IFX 投与中止率を新たに算出した。ささらに，成分栄養療法の 有無と投与量で分け，それぞれの治療成績も比較検討した【【方法】当 院において IFX0, 2, 6 週投与による緩解導入後, 8 週毎の計画的維持 投与を施行した 102 症例を対象とした。免疫抑制剤併用の有無・併用 時期を考慮し, (1) 治療開始から併用し継続投与 (62 例), (2) 治療開始 から併用し途中中断 (11 例)，(3) 治療途中から併用し継続投与 (12 例)，(4) 免疫抑制剤併用なし（17 例）の 4 群に分類した。 また，それ らを組み合わせて群を作り, それぞれについて, 緩解維持率, 無効・ 副作用による IFX 投与中止率を算出した. さらに, 治療開始時に免疫 抑制剂を併用した症例（73 例）について, 成分栄養療法の有無・投与 量 (900kcal 以上, 300 900kcal, 途中中止, 併用なし) で分け, 治療 成績を比較検討した.【成績】IFX 治療開始時に免疫抑制剂を併用した 群 $(1,2$ 群) は, 併用しない群 $(3,4$ 群) に比べ, IFX の無効・副作用 による IFX 治療中止率が大幅に減少した. 治療開始時から免疫抑制剂 併用を継続した 1 群と途中で中断した 2 群の間で治療成績に有意差は 認めなかった。 また, 治療開始時に免疫抑制剂を併用した群 $(1,2$ 群) における成分栄養療法の有無・投与量の比較では, 併用の有無・投与 量に関わらず, 治療成績に有意差は認めなかった.【結論】IFX 治療開 始時の免疫抑制剂併用は，臨床的に有用である。一方で，治療開始時 から一定期間併用した場合，途中中断しても緩解維持率は同程度であ り，開始時の併用が重要である事が示唆された。また，IFX 治療開始 時に免疫抑制剂を併用した場合に扔ける成分栄養療法の併用効果は, 投与量に関わらず同程度であり，この場合の併用は必ずしも臨床的に 重要であるとは限らないと考えられた。

\section{WS2-6 Crohn 病に対する Infliximab 維持療法の有用性と問題点}

北里大学東病院消化器内科

横山 薰, 小林清典

【目的】 Crohn 病 (CD) に対する抗 TNF- $\alpha$ 抗体 (Infliximab : IFX) によ る維持療法の有用性と問題点を明らかにする.

【対象】対象は当院で IFX 療法を行った CD46 例のなかで, IFX 投与を 4 回以上行った 33 例. 治療開始時年齢は $30.6 \pm 9.4$ 歳, 罪病期間は $8.0 \pm$ 6.8 年, 病型は小腸大腸型 $70 \%$, 大腸型 $27 \%$, 小腸型 3\% で, 腸切除の既 往を $27 \%$ に認めた。腸管合併症は狭窄 9 例, 外瘦 7 例, 内瘦 1 例, 痔瘦 12 例を認めた. IFX 療法開始時の IOIBD は $3.4 \pm 1.6$, CDAI $242 \pm 91$ で あった。

【検討項目】1）IFX 維持療法による累積宽解維持率や再入院率, 外科手 術の要否. 2) IFX 計画的維持投与の中止例および治療効果減弱例の解析 【成績】1）IFX の治療目的は, 腸管病変の改善 55\%, 㾇孔の改善 $6 \%$, 両方 $27 \%$, 術後再発 $12 \%$ であった. IFX 維持療法の平均治療期間は $2.4 \pm 1.8$ 年 (最長 6.2 年), 投与回数は $11.5 \pm 7.7$ 回 (最大 33 回), 投与法 は計画的維持投与 (schedule) 64\%, 症状出現時投与 (episodic) $15 \%$, episodic から schedule へ移行が $21 \%$ であった. IFX 療法開始時の併用 療法は, 5-ASA 製剤 94\%, PSL52\%, 経腸栄養療法 (900kcal/ 日以上) $67 \%$ であった。なお免疫調整郕（IM）は併用されていなかった，2)経過中に 再燃を 25 例 $(76 \%)$ で認めた。再燃時の内科治療は episodic から schedule 投与への移行 7 例, IM の追加 5 例, PSL の追加や増量 4 例, IFX 投与間隔の短縮 3 例（重複あり）などであった，累積寛解維持率は，治 療開始後 6 ケ月で $40 \%, 12$ ケ月で $27 \%$ であった。 なお寛解を維持でき た 8 例は, 全て schedule 投与例であった. 3) IFX 療法導入前に入院治療 を 31 例 $(94 \%)$ で要したが，導入後は 11 例 $(33 \%)$ 一減少した。外科 手術は痔瘦に対して seton 法を 5 例に行ったが, 腸切除例はなかった. 4) 維持療法の中止は 9 例 $(27 \%)$ で, 中止理由は症状悪化 4 例, 副作用 2 例，転居 2 例，患者の希望 1 例であった. Schedule 投与中に治療効果の 減弱を 6 例 $(18 \%)$ で認めた。 IFX 投与間隔の短縮や，IM または PSL の追加を各 4 例（重複あり）に行ったが，2 例は維持療法を中止した 【結論】CD に対する IFX 維持療法は, 再燃による入院治療や外科手術の 回避, QOL の改善に有用と考える. しかし治療効果が減弱する症例もあ り,さらなる治療法の工夫が必要である。

\section{WS2-7 インフリキシマブ使用後手術例の検討}

横浜市立市民病院外科 ${ }^{1}$, 横浜市立大学市民総合医療センター難病医 療センター ${ }^{2}$, 松島クリニック ${ }^{3)}$ 小金井一隆 ${ }^{1)}$ ，杉田 昭 ${ }^{1)}$ ，木村英明 ${ }^{2)}$ ，黑木博介 ${ }^{12}$ ，鬼頭文彦 ${ }^{1)}$ ， 福島恒男 ${ }^{3)}$

インフリキシマブ (以下, IFX) はクローン病の治療薬として有用で広 く使用されている。一方, IFX を使用しても手術を要する症例もあり, 手術例からみた IFX 治療の課題を検討した。【対象】2006 年以降に当 科でクローン病に対し, 手術を施行した 389 例中術前にIFX を 3 回以 上使用した 50 例（男性 31 例，女性 19 例）で，小腸大腸型 36 例，小 腸型 9 例, 大腸型 5 例, クローン病発症時の平均年齢は 19 歳 (12-35), 手術時平均年齢は 31 歳（19-57）であった。 21 例に scheduled maintenance 投与が行われていた.【方法】IFX 治療の適応となった病変, 手術 適応となった病変, 手術時の問題点について検討した.【結果】 1 : IFX 治療の適応となった病変は, のべ症例数で活動性病変 17 例, 内瘦 16 例 (腸管膀胱㾇 9 , 腸管腸管㾇 4 , 腔㾇 3 ), 腸管狭窄 11 例, 痔㾇 9 例, 腸管皮膚瘦 6 例であった. $2:$ 手術適応となった病変は IFX の適応病 変と同じであった症例が 31 例, I FX の適応病変に IFX 投与開始後に 生じた新たな病変が加わった症例が 17 例, IFXの適応となった病変 は改善したものの新たな病変が生じた症例が 2 例であった．新たに生 じた病変は狭窄 14 例, 膿瘍 4 例（後腹膜膿瘍 2 , 直腸周囲膿瘍 2 ), 内 瘦 2 例, 腔瘦 1 例であった。新たに病変を生じた 19 例中 16 例に scheduled maintenance 投与が行われていた。活動性病変に対し IFX が投与された 17 例中 14 例に狭窄が, 4 例に膿瘍が生じていた. $3:$ 腸 管皮膚瘦，腸管腸管瘦，腸管膀胱瘦のいずれかを合併した 15 例中 8 例では術中所見で正常腸管が主病変の inflammatory mass に巻き込ま れており，合併切除を要した.【結語】IFXをクローン病の活動性病変 の治療に使用する場合, 病変部の狭窄, 周囲の膿瘍が発生する場合が あり留意が必要である，㿉孔を伴う病変に使用する場合，周囲正常腸 管を巻き込み切除を要する可能性があるため, 適切な時期に手術を行 う必要がある.クローン病の複雑な病態に応じて IFX の適応を決定す ることが重要と考えられた。 

$\begin{array}{ll}\text { WS2-8 } & \text { 当科におけるインフリキシマブ導入前後でのクローン病術 } \\ \text { 後維持療法の变遷と再発率の比較 }\end{array}$

九州大学病態機能内科学

江崎幹宏, 松本主之, 矢田親一朗, 飯田三雄

[背景と目的] 栄養療法はクローン病 $(\mathrm{CD})$ に対して術後再発予防効果 を有するが, 患者のコンプライアンスは必ずしも高くない。近年，イ ンフリキシマブ (IFX) が術後再発予防効果を有することが示されてお り，CDの術後療法も様変わりすることが予想される。 そこで, IFX 導入前後での CD 術後療法の変遷と再発率を比較した. [対象と方法] 2003 年 5 月以前に手術を施行し栄養療法による術後維持療法が推奨 された 36 例 (IFX 導入前群) と，2005 年 8 月以降に手術が施行され術 後早期より IFXの計画的維持投与が行われた 20 例 (IFX 導入後群)を 対象とした。臨床像（発症年齢, 罹病期間, 既手術歴の有無, 病変範 囲, 臨床病型, 活動性肛門病変の有無)ならびに術後療法(栄養療法, 5-ASA，PSL，免疫抑制剂，IFX)を遡及的に検討し，2 群における栄 養療法のコンプライアンス, 再発率の比較を行った。 なお, 栄養療法 は全観察期間で $\geqq 1200 \mathrm{kcal} /$ 日の経腸栄養剤服用が継続できた症例を 栄養療法ありとし, 術後再発は CDAI 150 かつベースラインと比較 して $\Delta \mathrm{CDAI} \geqq 70$ を満たした時点で術後再発ありと定義した. [結果] (1) IFX 導入後群では導入前群と比較して有意に 5-ASA, 免疫抑制剂 の併用例が多かった $($ 順に $\mathrm{p}<0.0005, \mathrm{p}<0.05)$ ． 栄養療法に関しては, IFX 導入前群 36 例中 13 例が退院後 1 ケ月の時点で継続困難となり, 最終的に栄養療法ありと判定できた症例は 19 例 (53\%) であった。導 入後群では 6 例 $(30 \%)$ で栄養療法が併用されいずれも継続できてい たが, 導入後群で栄養療法実施例は有意に少なかった $(\mathrm{p}<0.01)$. (2) IFX 導入前群では平均 30 ヶ月の経過観察期間中 22 例 $(61 \%)$ で 再発が確認された。一方, IFX 導入後群では平均 13 ヶ月の観察期間中 再発は 1 例のみで, IFX 導入後群で術後再発率が低い傾向が見られた $(0.05<\mathrm{p}<0.1)$. [結論]IFX の計画的維持投与により術後の栄養療法選 択の機会は減少したが, 本治療は良好な術後再発予防効果を発揮する 可能性が示唆された.

\section{WS2-9 クローン病術後再燃に対するインフリキシマブの有効性に 関する内視鏡的検討}

慶應義塾大学包括先進医療センター ${ }^{11}$, 慶應義塾大学医学部消化器内 科 ${ }^{2)}$, 慶應義塾大学病院内視鏡センター ${ }^{32}$

井上 詠 ${ }^{1}$, 長沼 誠2), 岡本 晋 ${ }^{2}$, 今枝博之 ${ }^{3)}$, 緒方晴彦 ${ }^{3)}$, 岩男 泰 ${ }^{12}$, 日比紀文 ${ }^{2)}$

【目的】クローン病 $(\mathrm{CD})$ は手術後にも高率に再手術を要することが報 告されており, 術後早期に病変が再燃している可能性が考えられる. 今回, バルーン小腸内視鏡 $(\mathrm{BE})$ を用いて CD 術後患者における小腸 病変について検討し，インフリキシマブの術後小腸病変に対する有効 性について考察を行なった.【方法】CDに対してBEを行なった 54 例中 $\mathrm{CD}$ 術後 3-15 ケ月に $\mathrm{BE}$ (すべて経肛門的)を施行した 20 例を対 象に, $\mathrm{BE}$ 施行前後の治療内容, 活動度, 内視鏡所見について検討した. 内視鏡活動度は Rutgeerts の分類（0-4）を使用した。臨床背景は BE 施行時の平均年齢 32.7 歳, 平均罹病期間 5.6 年 (1-18 年), 小腸型 7 例, 小大腸型 13 例で直近手術術式は回腸部分切除 12 例, 回盲部切除 5 例, 回腸部分切除+結腸切除 3 例で, 残存小腸は $286 \mathrm{~cm}$ であった。 【成績】1）内視鏡所見：2 例以外は BE 施行時に臨床的に緩解維持 (平 均 CDAI110)されており, 内視鏡活動度は CDAI と相関はなかった。 強度癒着例 3 例以外は吻合部までの観察が可能であった。活動度は Rutgeerts 分類 0-1:10\%,2:30\%, 3:25\%, 4:35\% であった. 病変部 位は吻合部潰瘍 $94 \%$ (16/17), 吻合部以外の小腸病変 65\% (13/20) が 多く，盲腸 $(33 \%)$ ，盲腸以外の大腸（15\%）は少なかった。 2$) \mathrm{BE}$ 施行前後の治療法の推移 : 術直後の治療は 5-ASA 製剂のみ・6-MP/ AZA (IFX 非投与) 14 例，IFX 使用 6 例であったが，IFX 非投与例の うち 13 例 $(94 \%)$ に Rutgeerts 2 以上の病変が認められ，そのうち 11 例に IFX が投与された．3）内視鏡所見を認めたためIFXが投与され た 11 例のうち再度 BE にて経過を観察しえた 7 例では, 回腸・大腸病 変はほぼすべての例で改善・治瘉を認めたが, 吻合部の病変は 7 例中 4 例で改善が認められなかった. 臨床的には 7 例すべてで寛解が維持 されていた.【結論】術後 CD の回腸・大腸病変に対して IFX を投与す ることにより粘膜治癒が得られ， BE が粘膜病変の評価・治療方針の 選択に有用であると考えられた.一方, 吻合部病変は CD の活動性とは 関係ない可能性が考えられた。

\section{WS2-10 難治性クローン病に対するレミケード治療の臨床的検討}

松島病院大腸肛門病センター

辺見英之, 福島恒男, 西野晴夫, 森岡 香, 中条徹朗, 田中良明, 野沢 博, 高橋敬二, 松島 誠

【目的】難治性クローン病 $(\mathrm{CD})$ に対するレミケード (インフリキシマ ブ）の治療効果を報告する.【対象】当院で加療中の $\mathrm{CD}$ 患者 24 例（平 均発症年齢 $20.6 \pm 5.6$ 歳, 平均罹患期間 $10.4 \pm 10.1$ 年, 男女比 $16: 8$, 小 腸大腸型 16 例，大腸型 7 例，小腸型 1 例，肛門病変合併例は vaginal fistula3 例を含む 19 例）を対象とした.【方法】レミケードは 0 週，2 週，6週，その後 8 週間隔のスケジュール投与を行った. CD の臨床的 活動性は IOIBD score, CRP で評価した。痔瘦は肚門所見, 経肛門的 エコー所見，一次病変の内視鏡所見をそれぞれ治療前後で観察し，治 療効果を検討した。【結果】治療後に腹部症状, 関節痛, 肛門痛などが 軽快し QOL の改善した症例を 77.8\% に認め, IOIBD score は治療前 $(3.67 \pm 1.81)$ から治療後 $(1.81 \pm 1.10)$ 一と有意に低下し $(\mathrm{p}<0.001)$, CRP も治療前 $(2.94 \pm 2.53)$ 加治療後 $(0.71 \pm 0.78)$ へと有意に低下 した $(\mathrm{p}<0.001)$. 肛門所見は肛門周囲の炎症の鎮静化および瘦管から の discharge の減少消失 $(88.2 \%)$ や 2 次口の㓔痕閉鎖 (29.4\%) を認 めた. drainage seton が挿入されていた 13 人中 4 人 $(30.8 \%)$ は seton 抜去したが, setonの再抻入例を 1 例認めた. 経肛門エコーでは治療前 に存在した比較的細い㾇管は hyperechoic な像で描出され, 病巣の瘏 痕繊維化の状態と考えられた一方，太い瘦管は hypochoic な像として 描出され不良肉芽などわずかな炎症所見と考えられた。内視鏡検査に よる一次病変の評価では, 周囲に強い炎症を及ほしていた潰瘍が, 治 療回数と共に炎症が鎮静化し pinhole 様になり治癒傾向を認めた。ま た治療後では，ステロイド剂を内服していた 8 人全員が離脱した。成 分栄養療法との併用療法を維持しているのは 14 人中 11 人であった. 副作用はアレルギー症状を認めた症例を 5 例 $(20.8 \%)$ 認めたが, 治療 前にステロイドや抗ヒスタミン剤を使用してレミケード治療の継続が 可能であった，投与間隔は緩解状態が維持でき治療間隔の延長例があ る一方, 5 例は次回の治療まで緩解状態が維持できないため, 間隔を縮 めている.【結語】CD 患者の多くがレミケードの治療後, 著明に改善し 寛解を維持しており, 有用な治療法と考える.

\section{WS2-11 クローン病肛門病変に対する術後 Inflixmab 投与の効果}

兵庫医科大学下部消化管外科 ${ }^{1)}$ ，兵庫医科大学下部消化管科 ${ }^{2)}$, 兵庫医 科大学感染制御学 ${ }^{3)}$

内野 基 ${ }^{1)}$, 池内浩基 ${ }^{1)}$, 蝶野晃弘 ${ }^{1)}$ ，松岡宏樹 ${ }^{1)}$, 松本譽之 ${ }^{21}$, 竹末芳生 ${ }^{3)}$, 冨田尚裕 ${ }^{1}$

【背景】クローン病 $(\mathrm{CD})$ の肛門病変は複雑痔瘦を形成し難治性である. その手術治療は姑息的な seton ドレナージが選択されることが多く 人工肛門造設術を必要とする場合も少なくない。近年, 肛門病変の治 療に対して Inflixmab（IFX）の投与が有用であるとの認識が高いが, 長期的な予後は不明である。 今回，肛門病変に対し手術を行った症例 について IFX の効果, 術後経過, 予後を検討することとした.【対 象】1974 年 9 月から 2009 年 3 月に, 痔瘦, 肛門周囲膿瘍が手術適応と なった CD130 例中, 経過観察が可能であった 62 例を対象に IFX 投 与, 非投与群に分けて検討した。検討項目は術後短期 (3 ケ月)および 観察期間中の再燃率，人工肛門造設率とした.【結果】IFX 投与群は 26 例，非投与群は 36 例であった。術後観察期間は投与群 $28.2(0.57-$ 157.4), 非投与群 74.5 （7.4-218.9） か月で有意に非投与群で長かった $(\mathrm{p}<0.01)$. 術後短期（3 か月）での肛門病変の経過は投与群で軽快 $84.6 \%(22 / 26)$, 非投与群で $91.7 \%(33 / 36)$ と良好な結果で, 有意差 は認めなかった $(\mathrm{p}=0.39)$. 全観察期間でも投与群軽快率 $65.4 \%$ (17/ $26)$, 非投与群 $52.8 \%(19 / 36)$ と有意差は認めなかった $(\mathrm{p}=0.32)$. し かし投与群では観察期間中の軽快率が短期 84.6\% (22/26) から $65.4 \%$ $(17 / 26)$ の減少であったのに対し $(\mathrm{p}=0.11)$, 非投与群では観察期間の 延長とともに $91.7 \%(33 / 36)$ から 52.8\%（19/36）と有意に寛解維持率 が低下していた $(\mathrm{p}=0.02)$. 投与群での再燃症例はすべて IFX 投与中 止後であり軽快を維持している症例の $76.5 \%$ （13/17） が維持投与を 行っている．肛門管狭窄は再燃群で $96.2 \%$ (25/26), 軽快群で $41.7 \%$ $(15 / 36), p<0.01$ と有意に再燃群で多かった。 人工肍門造設率は投与 群 11.5\% (3/26), 非投与群 55.6\% (20/36), p<0.01 と有意に投与群で 低かった.【結語】術後 2-3 年の IFX の肛門病変に対する効果は非投与 群に比べて高い結果であった。しかし観察期間は短く長期的な経過観 察が必要である 
WS2-12 画像所見を加味したクローン病痔瘦に対するインフリキシ マブ治療の検討

福岡大学筑紫病院外科 ${ }^{1)}$, 福岡大学筑紫病院消化器科 2$)$

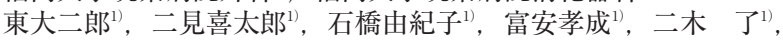
前川隆文 ${ }^{11}$ ，小野陽一郎 ${ }^{2)}$, 松井敏幸 ${ }^{2)}$

【目的】クローン病 (以下 CD) 肚門病変, とくに痔癭病変に対してイ ンフリキシマブ（以下 IFX）が投与されることが多くなり，その有用 性は短期的には多くの報告がみられる。 今回, 自験例の長期経過を MRI 検查所見を加味して検討し, IFX の治療戦略を考察した.【対象と 方法】 2007 年 12 月までに CD 痔㾞に対し IFX 治療を行った症例は 30 例で平均観察期間は $46.1 \pm 23.0$ ケ月であった。 IFX 投与後追加治療を 必要とせず経過した症例を「IFX 単独群」, IFX 以外の治療として抗生 剂投与など外科処置以外の治療を行なった症例を「中間群」, 外科処置 が必要であった症例を「外科介入群」として 3 群に分け検討を行った. 治療前に MRI 検査を行なった症例については, 痔瘦の形態を限局型 (㾇管が追え, かつ瘦管の壁が確認できる)びまん型(瘦管が追えない, または㾇管の壁が確認できない)，隔壁型（㾇管内に隔壁を認める）の 3 所見から治療後の経過を追った。 また継続性について調査し IFX の使用法の検討を行った.【結果】IFX 投与後の経過では IFX 単独群 10 例 (33.3\%), 中間群 6 例 (20.0\%), 外科介入群 14 例 (46.7\%) であっ た. 治療前に MRI を施行した症例は 13 例あった。経過との関連は限 局型 5 例のうち 4 例は IFX 単独群，1 例は中間群であった。びまん型 5 例はすべて外科介入群で, 隔壁を伴う 3 症例は 1 例が中間群, 2 例が 外科介入群であった. IFX 継続状況では一旦中断し再開した症例を含 め投与継続している症例が 18 例, 一定の効果は認めたが中止した症例 が 2 例, 効果がなく中止した症例が 10 例であった. IFX 単独群は全例 継続中であるが, 外科介入群 14 例中 6 例 (42.9\%) が IFX 治療を続け ていた、【結語】 CD 痔瘦に対する IFX の治療戦略としては, MRI 所見 を加味した適応とともに, 局所感染巣のコントロールを図るための適 切な外科治療の介入が重要と考える.

\section{WS3-1 キャンピロバクター腸炎 39 例の臨床的検討}

大腸肛門病センター高野会くるめ病院1), 久留米大学消化器内科 ${ }^{2)}$, 久 留米大学外科 ${ }^{3)}$

小篠洋之 ${ }^{1)}$, 荒木靖三 ${ }^{1)}$ ， 野明俊裕 ${ }^{1)}$ ，中川元典 ${ }^{1}$ ，岩谷泰江 ${ }^{1)}$,

鍋山健太郎 ${ }^{1)}$, 高野正博1), 光山慶一 ${ }^{2)}$, 白水和雄 ${ }^{3)}$

【目的】キャンピロバクター腸炎は感染性腸炎として臨床的に遭遇する 機会が多く，また内視鏡像が潰瘍性大腸炎に類似することもあり鑑別 が重要である。そこで本疾患の臨床的特徵を明らかにする目的で当院 において経験した 39 例を retrospectiveに検討した.【対象と方法】 2007 年 1 月から 2008 年 12 月までに便培養検査で Campylobacter jejuni（以下 C.jejuni と略）陽性であった 39 症例を対象とした【成績】 (患者背景)男性 24 例，女性 15 例，平均年齢は 35.9 歳であった。年齢 別の発生数では男女とも 20 歳代がそれぞれ 8 例, 5 例と最も多かっ た. 月別の発生件数では 4 月から 6 月に多く発生していた. (臨床像) 初 発症状は下痢が最も多く(約 $97.4 \%)$, その他に腹痛, 発熱, 嘔気など を認めたが湢吐を認める症例はなかった。また血便は 7 例 (約 $17.9 \%$ ) に認めた. 発症前の食事内容が確認できた 14 例のうち䳕肉関連食品の 摄取既往があったのは 7 例であった. (検査結果) 便培養検査では全例 C.jejuni が検出され同定までに平均 5.1 日間を要した。 (内視鏡所見) S 状結腸内視鏡検查は 37 例に施行され発赤や粘膜の浮腫, 褐色調の出血. 班，粗雑・顆粒状粘膜，びらんといった所見が直腸から S 状結腸にか けてびまん性あるいは散在性に認められるが血管透見像の良好な粘膜 が介在することが潰瘍性大腸炎との相違点と思われた。また 9 例に対 し全大腸内視鏡検査が施行され回盲弁のびらん・潰瘍を 4 例に認め た. (病理学的所見) 腺管構造は比較的保たれているが, 杯細胞の減少 や陰窩炎・陰窩膿瘍を認め, 粘膜固有層内一の好中球・リンパ球・形 質細胞といった炎症細胞の浸潤が種々の程度で認められた。 (治療) 対 処療法のみで症状が軽快したのは 30 例で 9 例は入院治療を要したが 平均 8.7 日間で全例軽快退院となった。ニューキノロン系抗菌薬の耐 性率は約 30\% であった.【結論】本疾患は感染性腸炎として遭遇する頻 度が比較的高いため, 詳細な問診と臨床症状, さらに内視鏡検査によ る特徴的な所見が診断に重要であると思われる。

\section{WS3-2 アメーバ性腸炎の臨床的検討}

国立国際医療センター戸山病院 永田尚義

【背景と目的】近年，アメーバ腸炎は性行為感染症として国内感染が急 増している. 本疾患は臨床所見, 内視鏡像から積極的に疑わなけれれ ば診断に難渋することもある. 今回, 性行為感染症や HIV 感染症の診 療機会が多い当院で, アメーバ腸炎患者を対象に, 1 診断方法, 2 臨床 像, 3 内視鏡所見, 4 治療後効果を明らかにする事を目的とした. 【対象】 2002 年から 2009 年 4 月の期間, 大腸内視鏡検査が施行されアメーバ 腸炎と確定した 41 例。治療開始例は除外した.【方法】確定診断は，内 視鏡所見に加え以下検査のいづれかが陽性の場合とした。検査は抗体 法 (ELISA 法), 生検法 (HE と PAS), 便鏡検, 便 PCR 法である。調 查項目は, 各種検査の陽性率, HIV, 梅毒, HBV 感染合併の有無, 海 外渡航歴, 症状, 肝膿瘍合併有無, 内視鏡所見（たこいぼ, びらん・ アフタ, 潰瘍, 白苔の 4 つの所見と全周性の有無), 治療効果 (期間と 治療後の生検㓌性率）である.【結果】 41 例の内訳は男/女 $39 / 2$ 例, 年 齢中央值 40 歳 (19-77) であった. 1, 診断方法 : 抗体法は 89\% (33/37), 生検法は 83\% (33/40), 便鏡検 18\% (4/22), 便 PCR100\% (5/5) で 陽性あった．抗体法陽性者でも 4 例が生検法陰性 $(\mathrm{HIV}+4$ 例)であり, 生検法陽性者でも 4 例が抗体法陰性 (HIV + 3 例だが AIDS 例なし) で あった。2, 臨床像：HIV 陽性は 63\%（26/41），梅毒陽性は 29\%（10/ 34), HBV 陽性は 8\% (3/40)。感染リスクは海外渡航歴 2 例で, homosexual23 例 (最多), bisexual3 例，不明 18 例であった。肝膿瘍は $17 \%$

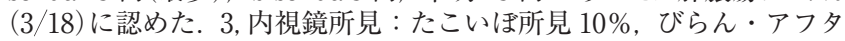
$75 \%$, 潰瘍 $40 \%$, 白苔 $90 \%$, 全周性 45\% であった. 4 , 治療効果：内 視鏡 follow 可能症例は 16 例. MNZ の平均投与量は $1233 \mathrm{mg}$, 平均投与 日数は 12.5 日であり, 生検でのアメーバはすべて陰性であったが抗体 法は陽性であった.【結語】アメーバ腸炎を疑うきっかけとして，内視 鏡像では白苔とびらん所見, 患者背景では若年男性, homosexual が重 要である。診断のための検査として抗体法は陰性例がある事，過去の 感染を反映し偽陽性例がある事に注意が必要である。診断に至った場 合は, 他の性行為感染症（梅毒, HIV）の追加評価が必要と考える.

\section{WS3-3 サイトメガロウイルス（CMV）腸炎の臨床的検討}

大阪市立総合医療センター消化器内科

大川清孝, 上田 涉, 佐野弘治

【目的】 CMV 腸炎の臨床像について検討する.【対象と方法】当院で経 験した CMV 腸炎 31 例について, 性・年齢, 基礎疾患, 薬剤, 臨床症 状, 病変部位, 内視鏡像, 確定診断の方法などについて検討した.【成 績】性別は, 男 20 例，女 11 例で男に多かった。年齢は先天性 AIDS 症例を除けば 29〜81 歳であった。基礎疾患は AIDS9 人，悪性疾患 7 人, 移植後 3 人, 膠原病 3 人であった。 その他に外傷 3 人, 急性腎不 全が 2 人みられた。薬剤は副腎皮質ホルモン 13 人，免疫抑制剤 6 人， 抗癌剤 6 人であった。症状は血便 18 人，下痢 11 人であった。穿孔は 5 人にみられたが, 4 人は小腸穿孔であった。 病変部位は一定の傾向が なかったが，回盲弁上の潰瘍が 4 人にみられた。内視鏡像は多彩であ り，うち抜き様潰瘍，浅い不整形潰瘍，輪状傾向潰瘍，帯状潰瘍，縦 走潰瘍，アフ夕様潰瘍の順に多かった。 その他の所見として偽膜を伴 うもの, 周囲粘膜の浮腫などがみられた，確定診断の方法では封入体 の検出が 24 人, CMV アンチゲネミア 2 人, 組織 DNA 4 人, 血中 DNA 1 人であった. 【考察】基礎疾患や薬凨については, いわゆる compromized host が多いが, それ以外に外傷や急性腎不全もみられ，注意 する必要があると考えられた，症状については血便が多く，緊急内視 鏡を行われている症例も多く, 鑑別疾患として必ず考慮する必要があ ると考えられた。少腸穿孔も比較的多くみられ，やはり鑑別疾患とし て考慮する必要がある。内視鏡像では従来から言われているうち抜き 様潰瘍が最も多いが, その他にも多彩な内視鏡像を呈する. 確定診断 に関しては, 封入体や CMV アンチゲネミアが陰性となる症例があり, その場合には積極的に組織 DNA や血中 DNA の検索を行う必要があ ると考えられた. 非常に大きな潰瘍でも, 封入体や CMV アンチゲネミ アが陰性となる症例もあり, 注意が必要である。 

WS3-4 移植後患者の Graft-versus-host disease 腸炎とサイトメガ
ロウィルス腸炎

九州大学病態機能内科学

梁井俊一, 松本主之, 森山智彦, 藤澤律子, 中村昌太郎, 飯田三雄

【目的】Graft-versus-host disease（以下 GVHD）腸炎は臟器移植後に 発生する炎症性腸病変である。一方，移植後にはサイトメガロウィル ス $(\mathrm{CMV})$ 腸炎も高率に認められる。我々は移植後患者にみられた大 腸病変の内視鏡像と病理学的所見について検討した.【対象と方法】同 種造血幹細胞移植, 肝移植, 肺移植後に消化器症状が出現した患者の うち，当科で下部消化管内視鏡検査を行った 31 例を遡及的に検討し た. 生検標本の病理学的所見に基づいて GVHD 腸炎, CMV 腸炎, な いし両者の合併に分類した. 内視鏡所見は血管透見像の消失, びらん・ 潰瘍性病変, 亀甲状粘膜模様, 粘膜浮腫に大別して検討した。また, 12 例では治療前後の内視鏡所見の推移についても検討した.【結果】男 性 23 例, 女性 8 例で, 年齢は 20 歳から 68 歳 (平均 48 歳)であった。 移植から内視鏡検査までの期間は 17 日から 862 日（平均 104 日）で あった，病理組織所見から 26 例 $(83 \%)$ が GVHD 腸炎で，そのうち 7 例で CMV 腸炎の合併が認められた. CMV 腸炎のみの症例はなかっ た. GVHD 腸炎単独例 (19 例)では血管透見像の消失を 17 例 (89\%), びらん・潰瘍性病変を 7 例 $(36 \%)$, 亀甲状粘膜模様を 14 例 $(73 \%)$, 粘膜浮腫を 14 例 (73\%) に認めた。一方, GVHD 腸炎と CMV 腸炎合 併 $(7$ 例 $)$ では血管透見像の消失を 7 例 $(100 \%)$, びらん・潰瘍性病変 を 6 例 (85\%), 亀甲状粘膜模様を 7 例 (100\%), 粘膜浮腫を 6 例 $(85 \%)$ に認めた. 治療経過が追跡できた 12 例のうち 8 例は GVHD 腸炎症例, 4 例は GVHD 腸炎と CMV 腸炎合併例であった。改善したものが 5 例, 不変ないし増悪したものが 7 例であった，改善率は GVHD 腸炎症 例で $50 \%$ （8 例中 4 例）， GVHD 腸炎と CMV 腸炎合併例で $25 \%(4$ 例中 1 例）であった.【結論】GVHD 腸炎の内視鏡所見として，血管透 見像の消失や亀甲状粘膜模様が特徴的と考えられた. GVHD 腸炎の難 治性が示唆された。

\section{WS3-5 我が国における特殊な腸管感染症 腸管粘膜の白色絨毛を呈 する疾患〜粪線虫症と Whipple 病〜}

琉球大学光学医療診療部 ${ }^{1)}$, 琉球大学医学部第一内科 ${ }^{2)}$

知念 寛 ${ }^{1)}$, 岸本一人 ${ }^{1)}$, 金城 渚 ${ }^{1)}$, 外間 昭 ${ }^{2)}$, 金城福則 ${ }^{11}$

我々の施設が存在する沖縄県は，我が国の中では亜熱帯島嶼という極 めて特異な環境に位置しており，同地においては日本本土では稀な腸 管感染症に遭遇する事がある. 今回はその中でも, 内視鏡検査における 腸管粘膜の白色絨毛状の所見が診断に有用と考えられる特殊な腸管感 染症として, 粪線虫症とWhipple 病を取り上げ, 両疾患についての我々 の経験を述べる。

糞線虫症 (Strongyloidiasis) は糞線虫（Strongyloides stercoralis）によっ て起こる寄生虫感染症の 1 つである. 糞線虫はヒトに経皮的に感染し, 主に十二指腸や小腸上部に寄生する。わが国では沖縄県を含む南西諸 島に保虫者が多く存在するが, 自家感染により同一宿主内で数十年に わたり持続感染するため, 他の地域へ移住したこれらの地域の出身者 で発症することがある。糞線虫症は低蛋白血症や麻痺性腸閉塞が診断 の契機となることが多いが, HTLV-1 キャリアやステロイド・免疫抑 制剂等の投与で免疫能が低下した患者で重症化し, 播種性粪線虫症と しての細菌性肺炎や髄膜炎など致命的合併症で診断されることも少な くない.内視鏡所見としては粘膜ひだの腫大・混濁, びらん・潰瘍形成 などが観察され，白色絨毛状の所見を呈することもある. 確定診断には 普通寒天平板培地法による糞便培養検査が有用である.

Whipple 病は, 放線菌属のグラム陽性小桿菌である Tropheryma whipplei を原因とする慢性持続感染症である。通常は十二指腸から小腸の粘膜 に感染し下痢, 腹痛, 体重減少などをきたすことが多いが, 全身多臓器 に感染し多彩な症状を呈することもある。本邦での報告は疑診例を含 めても 10 例程度に過ぎず極めて稀であるが，我々は確定診断例を 2 例経験しており, 2 例とも HTLV-1 キャリアであった. 内視鏡検査での 腸管粘膜のびまん性の白色絨毛の所見が特徵的である. 生検組織で PAS 染色陽性の膨満したマクロファージが観察されれば本症が疑わ れ, PCR 法と電顕で T. whipplei の感染が証明されれば確定診断となる. 今回取り上げた 2 疾患はいずれも感染症であり, 診断に至れば治療は 可能であるが, 診断が遅れると致命的となることもある. 今回の発表が 診療の一助となることを望む。

\section{WS3-6ＮSAIDs 起因性大腸病変の臨床像と内視鏡像}

松山赤十字病院胃腸センター ${ }^{1)}$, 九州大学大学院病態機能内科学 ${ }^{2)}$ 蔵原晃一 ${ }^{12}$, 松本主之 ${ }^{2)}$, 飯田三雄 ${ }^{2)}$, 川崎啓祐 ${ }^{12}$, 㴊上忠彦

【目的】NSAIDs 起因性大腸病変の特徵を明らかにすること.【方法】松 山赤十字病院消化器科, 九州大学病態機能内科学および関連病院にお いて, 全大腸内視鏡検査を施行した症例のうち, 診断の確定したCrohn 病, 潰瘍性大腸炎, 腸管 Behçet 病などの炎症性腸疾患患者を除外した うえで, (1)大腸に局所性の潰瘍性病変ないしびまん性炎症性病変を認 め, (2) NSAIDs の使用歴が明らかで抗生剂の併用がなく, (3) 生検組織 もしくは切除標本組織で特異的炎症所見を認めず, (4)便あるいは生検 組織の培養検査が陰性で, (5) NSAIDs 中止後の病変の軽快ないし治㾑 を確認できた症例を NSAIDs 起因性大腸病変と診断してきた。これら の症例を対象として, その臨床像, X 線・内視鏡所見, および病理所 見を遡及的に検討した、成績】 37 例が診断基準を満たしていた。年令 は 22 歳から 81 歳 (平均 62 歳) で男性 16 例, 女性 21 例であった。病 変の形態から潰瘍型 27 例と腸炎型 10 例に分類できた. 潰瘍型 27 例中 1 例に膜様狭窄の合併がみられた。潰瘍型では 27 例中 21 例で経口な いし経肛門的にロキソニン, ジクロフェナック, ないしインドメタシ ンが投与されていたが, 腸炎型 10 例中 4 例ではメフェナム酸が投与さ れていた。潰瘍型のうち, 大腸 27 例中 25 例で右側結腸に病変を認め た。潰瘍型の特徴は回盲弁上，ハウストラ上の輪状傾向を有する境界 明暸な潰瘍に要約され, NSAIDs 投与中止数週後に痒痕化した. 潰瘍型 の組織所見として, 軽度の炎症細胞浸潤と核分裂像, あるいはアポトー シス小体が特徵的であった。腸炎型は，内視鏡的に出血性腸炎もしく はアフタ性腸炎の所見を呈し, 組織所見でも出血, 好酸球を主体とし た炎症細胞浸潤を認めた、【結論】大腸の潰瘍，狭窄，あるいはびまん 性腸炎では本症を念頭に置き，NSAIDs 投与歴を確認すべきと思われ た。

\section{WS3-7 Collagenous colitis の臨床病理学的特徵}

九州大学病態機能内科学 ${ }^{1)}$, 順天堂大学医学部人体病理病態学 ${ }^{2)}$

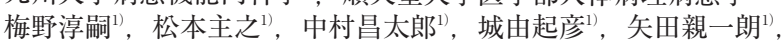
工藤哲司 ${ }^{11}$, 八尾隆史 ${ }^{2}$, 飯田三雄 ${ }^{1)}$

【背景】Collagenous colitis（CC）は, 難治性の下痢と粘膜上皮直下の collagen band (以下 $\mathrm{CB}$ ) の肥厚を特徵とする大腸疾患である.内視鏡 所見はほほ正常とされてきたが, 近年, 内視鏡的異常所見を認めた症 例も報告されている.【目的】CCの臨床病理学的特徵を明らかにする. 【対象】当科㧍よび関連施設で CC と診断された 24 症例を遡及的に検 討した.【方法】(1) 大腸の区域別に内視鏡所見の頻度, $\mathrm{CB}$ の厚さを比 較した。（2）ランソプラゾール（以下 LPZ）内服群（20 例）と非内服群 (4 例) に分け, 両群間の臨床背景, 内視鏡所見, 病理学的所見を比較 した. (3) LPZ 内服群（20 例）を, 縦走潰瘍のある群（11 例）とない 群 $(9$ 例) に細分し, 両群間の臨床背景, 病理学的所見を比較した.【結 果】(1) 全例で何らかの内視鏡的異常を認めた，縦走潰瘍は，直腸を除 く左側結腸を中心に分布していた. CB の厚さは, 上行〜 S 状結腸で厚 く, 盲腸や直腸で薄い傾向がみられた. (2) LPZ 内服群と非内服群で, 臨床背景に差はなかった。内視鏡的には, 縦走潰瘍を LPZ 内服群 20 例中 11 例 $(55 \%)$ に認めたが, 非内服群では 1 例もなかった $(\mathrm{p}=0.07)$. 組織学的には，LPZ 内服群で CB がより厚い傾向がみられた。 (3) LPZ 内服群のうち，縦走潰瘍のある群は，縦走潰瘍のない群より有意に女 性に多いものの, その他の臨床背景や病理学的所見に差はなかった。 【結論】左側結腸を中心に見られる縦走潰瘍の鑑別疾患としてCCは重 要と考えられた. 


\section{WS3-8 collagenous colitis $の 14$ 例}

福岡大学筑紫病院消化器科 ${ }^{11}$, 福岡大学筑紫病院病理部 2 石原裕士 ${ }^{1)}$ ，松井敏幸 ${ }^{12}$ ，原岡誠司 ${ }^{2)}$

【背景】CC は 1976 年に報告され，その後に独立疾患とされた。CC は画像検査所見を欠くことが特徴で, 病理組織学的に粘膜上皮下の厚 い collagen band (CB) を証明し診断される。近年 CC に粘膜面の異常 や血管異常などの内視鏡所見の報告や薬剤関連性を示唆する報告が増 えている.【目的と対象】自験 CC 症例の臨床像, 原因薬剤の頻度や内視 鏡所見を解析した。ささらに CB 厚の測定を行い内視鏡所見との相関を 分析することを目的とした．対象は 2001 年から 2009 年までに当院お よび関連病院で CC と診断された 14 症例.【方法】結腸の分節毎に内視 鏡所見と $\mathrm{CB}$ の測定・対比し, 内視鏡上異常所見部位では, その強度を 求めた。ささらに右側と左側結腸で異常所見の頻度を比較した.【検討項 目】1）内視鏡所見：結腸分節毎に内視鏡異常所見の強度を $0,1+, 2+$ と評価した. 2) CB の厚さと内視鏡所見の対比：CB の厚さが測定でき た 13 症例で, 右側結腸と左側結腸に分け厚さの平均值を算出した. $\mathrm{CB}$ 厚の平均值により肥厚群と非肥厚群とし両群間で内視鏡所見の強度の 差を求めた【結果】1. 臨床像; 性比は $4: 10$ と女性に多く, 平均年齢 74 歳. 原因薬剤として, Lansoprazole 11 例 (79\%), NSAIDs 3 例 $(21 \%)$ であった。原因薬剤の内服期間にはばらつきがあったが，原因薬荗の 中止で症状は改善した．2. 内視鏡所見；全体的には血管網増生が $78 \%$ と高頻度で, 色素散布による顆粒状粘膜も $65 \%$ であった。これらの所 見はいずれも右側結腸で多かった 1 例に, 線状縦走潰瘍も認められた. 3. 組織増との対比; 肥厚群と非肥厚群間で内視鏡所見の有無では $\mathrm{CB}$ の厚さに有意差を認めなかった【結論】自験 CC 全例が薬剤起因性で あり，原因薬剤中止で下痢症状は改善した。内視鏡では血管網増生と 顆粒像が高頻度であり, 右側結腸に多かった. 内視鏡所見の強弱と CB 厚は相関しなかった，以上より，本邦では薬片起因性 CC が多く, その 内視鏡所見は軽微なものであるが特徵的でもあった. しかし, CB の厚 さと異常所見は相関しなかった。

\section{WS3-9 夫婦発症を含む特発性腸間膜静脈硬化症についての検討}

弘前市立病院内科 ${ }^{1)}$, 弘前大学大学院医学研究科消化器血液内科学 ${ }^{2)}$, 弘前市立病院臨床検査科 ${ }^{3)}$

三上達也 ${ }^{1.2)}$ ，田中正則 ${ }^{3)}$ ，福田眞作 ${ }^{2)}$

大腸の炎症性疾患のなかで, 特発性腸間膜静脈硬化症は日本を含むア ジアを中心に報告されている比較的まれな疾患である。当科ではこれ まで夫婦発症を含む 4 例の経験がある.

本症の診断は, 腹部単純 X 線あるいは腹部 CT において主に右側の腸 管に沿った石灰化を認め, 下部消化管内視鏡では特徵的な暗青色〜青 銅色の色調変化を伴った粘膜を呈することから容易である。

発症要因に関してはいまだ明らかではないが，漢方薬の内服歴を有す る症例報告が散見されている。当科においても漢方薬の内服歴を有す る一組の夫婦での発症を認めており, 本症との因果関係が強く示唆さ れる.

症状は，他の疾患の精查中に偶発的に腹部 CT にて右側大腸に沿った 石灰化が見られ，全大腸内視鏡検査にて本疾患と診断された無症状の 症例から右下腹部痛を呈した症例, 腸閉塞を併発した症例と様々で あった。

内視鏡所見は全例で暗青色の色調変化を伴っており，びらんを有する ものから小潰瘍, 比較的大きな潰瘍を有するもの, 浮腫を伴うものが あり，これらの違いが臨床症状と関連すると思われた。

また, 通常侵される病変の範囲は右側の大腸から横行結腸までが多い とされているが, 腸閉塞を呈した症例では病理組織学的に回腸末端か ら直腸まで所見が得られており，稀な症例と考えられる。

発症後は，抗血小板薬などの内服を追加していないが, これまで全例 再発を認めていない. 症例の中には, 狭心症に対して抗血小板薬を内 服していたにもかかわらず，本症を発症したものもあり，発症後の維 持療法に関しては, 抗血小板薬を含め, 何らかの薬剂を投与すべきな のかどうか，またどのような症例に投与すべきなのかなど，今後の症 例の蓄積が必要と考えられる。

\section{WS3-10 特発性腸間膜静脈硬化症の検討}

札幌病院消化器内科 ${ }^{1)}$, 恵佑会札幌病院外科 ${ }^{2)}$

吉井新二 ${ }^{1)}$, 塚越洋元 ${ }^{11}$, 久須美貴哉 ${ }^{22}$, 鈴木康弘 ${ }^{2)}$

特発性腸間膜静脈硬化症 (idiopathic mesenteric phlebosclerosis；以下 IMP) は, 腸間膜静脈壁硬化に起因した還流障害による慢性虚血性の腸 病変である。1993 年に岩下らにより提唱された比較的新しい概念で, 稀な疾患ではあるが，近年報告が増加してきている．特徵的な画像所 見を知っていれば診断は比較的容易である為, 消化器科医師が知って おくべき疾患である.【症例 1】58歳, 男性. 漢方薬の服用歴がある. 便潜血陽性のため大腸内視鏡検査を施行．潰瘍や狭窄は認めなかった が右半結腸の粘膜は暗青色, 浮腫状であった。病理所見で粘膜下層の 膠原線維増生と血管壁の線維性肥厚を認め IMP と診断した. 腹部 CT で腸管周囲の石灰化はみられず，4 年の経過観察の間無症状無増悪で IMP の初期像と考えられた. 【症例 2】 54 歳, 女性. 漢方薬の服用歴が ある。右下腹部の違和感を主訴に受診。大腸内視鏡検査にて右半結腸 の粘膜は暗青色, 浮腫状で, 管腔は軽度狭小化し小潰瘍の形成がみら れた. 生検は粘膜固有層深側まで膠原線維の沈着を認めIMPに矛盾し ない所見であった．腹部 CT では右半結腸周囲の血管に石灰化を認め た. 3 年の経過観察で形態変化を認めていない. 【症例 3】57 歳, 女性. 既往に甲状腺機能低下症. 右側腹部痛を主訴に受診. 注腸 X 線では上 行結腸に狭窄を認め, 大腸内視鏡検査では回盲部から上行結腸が浮腫 状, 暗赤色調で厚い白苔を伴う潰瘍形成を認めた. 腹部 CT では上行結 腸周囲の血管に石灰化を認めた. IMP と診断し, 内科的治療をおこ なったが症状の改善が見られないため右半結腸切除術を施行した。病 理所見で粘膜下層の静脈壁の線維性肥厚と石灰化, 粘膜下層に著明な 膠原線維増生を認めた.【まとめ】右側結腸に好発し，肉眼所見は粘膜 面が暗青〜赤色の色調を呈し，全体に浮腫状，haustraは不明瞭とな る。進行とともに管腔狭小化を伴い，びらん，潰瘍を合併する。腹部 CT では腸管壁, 腸間膜に一致した石灰化が特徵的所見とされる.病因 は不明であるが漢方薬の可能性を示唆する報告が散見される。慢性に 経過し予後良好とする報告が多いが, 症状が増悪し外科手術を要する 例もあるため長期の経過観察が必要である。

\section{WS3-11 直腸粘膜脱症候群の臨床像や内視鏡所見についての検討}

北里大学東病院消化器内科

中目哲平, 佐田美和, 迎 美幸, 春木聡美, 横山 薰, 小林清典

【目的】直腸粘膜脱症候群 (mucosal prolapse syndrome: MPS) の臨床 像や内視鏡所見の特徵を明らかにする.【方法】当院で 1992 年以降に, 大腸内視鏡 $(\mathrm{CF})$ および生検組織所見から MPS と確定診断された 31 例を対象とした.MPSの診断契機や病変部位，CF で評価した直腸病 変の特徵などについて検討した。 また CFによる経過観察を行った症 例では, 治療による腸管病変の推移についても検討した.【成績】1) MPS 診断時の平均年齢は $48.2 \pm 18.0$ 歳（19～85 歳), 性別は男性 14 例，女性 17 例で女性がやや多かった。診断契機は血便が 15 例，検診 の注腸造影で異常指摘が 7 例, 下痢が 3 例, 便潜血陽性が 3 例, クロー ン病や骨転移の精査，大腸ポリープの経過観察が各 1 例であった。い きみの排便習慣はほぼ全例に認めた。 2) 直腸内での病変部位は, Rb が 26 例, Ra が 4 例, Rs が 1 例で, 多くは Rb に存在していた. 病型 は, 潰瘍型が 16 例 (52\%), 隆起型が 12 例 (39\%), 平坦型が 3 例 (9\%) であった. なお Raの 4 例は全て潰瘍型であった. 3) 内視鏡所見とし て, 不整形潰瘍 (5 例), 略円形潰瘍 (11 例), SMT 様隆起 (7 例), 結 節状隆起 (5 例), 扁平隆起 (3 例) などがみられ多彩なのが特徵的で あった。4)治療は, いきみの習慣の中止を主とした排便指導と緩下剂 の投与を行った。 5) CF による経過観察は 11 例で行い，平均観察期間 は $29.2 \pm 16.9$ 力月であった. 直腸病変の推移として, 潰瘍の㓔痕化や隆 起の消失を 6 例 $(55 \%)$, 潰瘍の縮小を 5 例 $(45 \%)$ で認めた.【結論】 MPS は幅広い年齢層でみられ，いきみの排便習慣を有していた．直腸 病変は $\mathrm{Rb} に$ に多く，大腸内視鏡所見は潰瘍や隆起など多彩な形態を呈 するのが特徴的であった。 


\section{WS3-12＼cjkstart放射線性腸炎に対する APC 治療}

大阪警察病院内科 ${ }^{11}$, 大阪警察病院内視鏡センター ${ }^{2)}$, 大阪警察病院外 科 ${ }^{3)}$

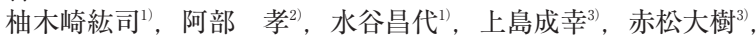
仲原正明 ${ }^{3)}$

【はじめに】放射線腸炎は骨盤内の悪性腫瘍の放射線治療後に主に直腸 と S 状結腸に生じる腸管合併症である。早期障害と晚期障害の 2 つに 分けられ，早期障害は自然治癒することが多い一方で晚期障害は治療 終了後 3 力月以降に出現し, 出血, 潰瘍形成, 狭窄, 㾇孔形成を主症 状とし, $5 \sim 10 \%$ に発症し，難治性である．今回，我々は放射線性腸炎 による出血に対する APC 治療の有効性について検討した.【対象】 1998 年 1 月 2008 年 9 月の 10 年間で当院にて病歴・大腸内視鏡所 見・生検組織像などから診断した晚期放射線腸炎 32 例について検討 した. またそのうち, APC 治療を行った 8 例についての検討も行った. APC 設定值は電力 $40 \mathrm{~W} /$ アルゴンガス流量 $1 \mathrm{~L} / \mathrm{min}, 1 \sim 2$ 秒の短時間 焼灼とした.【結果】平均年齢 71.8 (35 94 歳), 男 : 女 $=15: 17$, 原疾患 は子宮頸癌 13 例，前立腺癌 10 例などで照射線量 40.4 70Gy，障害部 位は直腸 21 例, S 状結腸 5 例などで, 内視鏡所見は Sherman 1a 24 例, $1 \mathrm{~b} 4$ 例, $2 \cdot 3 \cdot 4$ はそれぞれ 1 例ずつであった. 発病時期は放射線 治療終了後平均 1 年 11 力月 (4 力月〜 7 年) であった。 そのうち APC 治療を行った 8 例については非 APC 治療群と比較し照射線量がやや 多く, 内視鏡所見 Sherman $1 b$ の割合がやや高かった. APC 治療を 行った全例に症状の改善を認め，そのうち $75 \%$ （6 例/8例）に再燃を 認めなかった。全例に治療による合併症を認めなかった. Sherman 1 a で保存的加療や経過観察を行ったなかにも $10 \%$ (2 例 $/ 20$ 例) 増悪を 認めたが, APC 治療を行ったものは全例経過良好であった. Sherman $1 \mathrm{~b}$ では APC 治療を行ったものでも 3 例中 2 例に再燃を認め, 注意を 要すると考えられた【結論】晚期放射線腸炎では毛細血管拡張からの 出血が臨床上の問題となり, APC 治療は毛細血管拡張からの出血に対 し有効な止血法である可能性がある

\section{WS3-13 大腸咊室症に随伴するまれな病態}

大阪鉄道病院消化器内科 ${ }^{1)}$, 京都府立医科大学予防医学教室 ${ }^{2)}$ 清水誠治 ${ }^{1)}$, 清水香代子 ${ }^{11}$, 渡邊元樹 ${ }^{2)}$

本邦において大腸㮩室症は増加している，その合併症として出血，憩 室炎, 瘦孔, 狭窄などがよく知られており, とくに出血や悡室炎は日 常的に経験することが多い病態である。頻度は低いものの，これら以 外にも悡室症には様々な病態が随伴する。 今回はわれわれが経験した 大腸秝室症の随伴病変の内, 粘膜脱によると考えられるポリープ 3 例, 潰瘍性大腸炎類似の炎症像 2 例, filiform polyposis 1 例を提示する. 粘 膜脱によると考えられるポリープは” polypoid prolapsing mucosal fold”とも呼ばれ, 肉眼的には表面が平滑で発赤した大小の病変がみら れ, 組織学的には腺管の過形成, 毛細血管の増生, 粘膜固有層の線維 筋症がみられる。本病変の成因として, 悡室症腸管にみられる redundant mucosa に腸管蠕動の㠵進による肛門側への毫引や粪便による粘 膜損傷, さらにはうっ血や虚血性変化が加わって病変が形成されると 考えられている．潰瘍性大腸炎類似の炎症像は欧米で提唱されている diverticular colitis に含まれているが, この概念は本邦ではなじみが薄 い. diverticular colitis は大腸憩室を伴う腸管にみられる多彩な粘膜の 慢性炎症の総称で，憩室炎自体に伴う変化も含まれるが，㮩室炎を伴 わない場合や，憩室のない領域に発生することもある．前述の粘膜脱 の初期病変と考えられる病変も含まれているが，潰瘍性大腸炎や Crohn 病に類似した病像を呈することもある。本邦で受け入れられる ためには概念の見直しが必要と考えられる。 filiform polyposis は紐状 の炎症性ポリープが集簇多発する病変で，潰瘍性大腸炎やクローン病 に合併することがあると報告されている，ときに悡室が併存している 症例がみられるが, 熄室と filiform polyposis の関連を証明することは 難しい. 提示症例は上行結腸の filiform polyposis 術後の経過中に, 㮩 室のみがみられていた下行結腸に, 悡室炎による狭小化が起こり, 最 終的に filiform polyposis が形成されるまでを追跡できた症例である.

\section{WS3-14＼cjkstart腸管囊腫様気腫症 6 例の治療経験}

国立病院機構長崎医療センター外科 ${ }^{1)}$, 長崎県立島原病院外科 ${ }^{2)}$ 渡海大隆1)，永田康浩1)，原口正史 ${ }^{11}$ ，松尾繁年 ${ }^{2)}$

【背景】腸管囊腫様気腫症 (Pneumatoides cystoides intestinalis : PCI) は比較的稀な疾患であり, 成因や機序についても明確にはされていな い. 治療は原則として高圧酸素療法（HBO）などの保存的治療が有効 とされているが, 外科的治療を行うこともある.【目的】われわれが経 験した様々な病態の PCI について報告し，その多彩な臨床経過を検討 して PCI の成因や治療方針について考察する.【結果】症例数は 6 例で 平均 75.5 (56-94) 歳, 男女比 3:3 であった。腸管の壁内気腫が主に大 腸に存在する「大腸型」は 2 例でいずれも高齢者, 背景因子に便秘が 存在した。一方，主に小腸に気腫が存在する「小腸型」は 4 例で比較 的若年, 背景因子に一定の傾向は見られなかった。沉発性腹膜炎の所 見を認めた症例は無かった。腹腔内遊離ガスを来した症例は 2 例でい ずれも小腸型であった。門脈ガス血症を 2 例に認め, ともに小腸型で あった. ショックを併発した症例は 3 例で, 小腸 2 例, 大腸 1 例であっ た. 大腸内視鏡で診断された 1 例を除く 5 例では腹部 CT が診断に有 用であった．治療は HBO または高濃度酸素投与による保存的治療で 軽快した症例が 4 例であり，1例に対して手術を行なった. ショックと なった 3 例はいずれも集中治療室管理を要した。絶食のみで軽快した 1 例も認めた. 再発を 1 例に認めたが, すべての症例の治療経過は良好 であった【はとめ】PCIの成因については多様な要素が考えられ, 明確 な機序は特定できなかったが，大腸型では便秘等の腸管内压上昇が原 因の一つと考えられた．腸管内圧上昇に伴う PCI は慢性的で比較的軽 症である一方, 小腸型では門脈ガス血症やショックなど重篤な状態を 呈することも少なくなく, 早期に HBO 導入などの治療を行い, 注意深 い経過観察が必要である.

\section{WS3-15 当院で経験した腸管囊胞様気腫症例}

札幌厚生病院第一消化器科

黒河 聖, 今村哲理

腸管囊胞様気腫症（pneumatosis cystoides intestinalis : PCI）は，腸管 の粘膜下，あるいは漿膜下に多発性の囊胞状の気体貯留を認める病態 で，比較的に稀な疾患であるが，本邦では 500 例以上報告されている. 今回, 当院で経験した PCI 症例について検討した，症例は 6 例．男性 1 例, 女性 5 例. 平均年齢は 55.8 歳. 症状は下血 4 例, 腹痛 2 例. 基礎 疾患に潰瘍性大腸炎を認めたものは 1 例, 他は基礎疾患を認めなかっ た。病変は大腸型 5 例. 小腸型 1 例. 診断は大腸内視鏡検査で発見さ れたものが 5 例, 腹部 CT 検査で診断されたものが 1 例. 治療法は経過 観察のみの無治療例が 5 例, 腹腔内遊離ガス像を認めた 1 例は, 入院 後, 絶食・高カロリー輸液の保存的治療にて軽快した. PCI の成因につ いては，機械説，細菌説，慢性肺疾患説，化学説などが考えられる. 基礎疾患の有無により特発性と続発性に分けられ，発生部位にて，小 腸型と大腸型に分類される。一般的には男性に多く, 症状としては, 腹痛，下痢，下血を認めることがあるが，無症状な場合も多い。診断 は大腸内視鏡検査で大小不同の粘膜下腫瘍様の隆起が多発し，発赤や びらんを伴うこともある。治療法は，有症状例に対しては，高圧酸素 療法などの保存療法が一般的であるが, 消化管穿孔や絞扼性イレウス を合併した場合は手術適応となる。また，治療を必要とせず自然消失 もあり，当院で経験した症例も保存的に軽快し，腹腔内遊離ガスを認 めた症例も手術を回避できたため報告する。 


\section{WS4-1＼cjkstart若年者における肛門失禁の現状}

藤田保健衛生大学消化器外科 ${ }^{1)}$, 野垣病院 ${ }^{2}$

前田耕太郎 ${ }^{1}$, 花井恒一 ${ }^{1)}$, 佐藤美信 ${ }^{1)}$, 升森宏次 ${ }^{1)}$, 小出欣和 ${ }^{12}$,

松岡 宏 ${ }^{1}$, 勝野秀稔 ${ }^{1)}$, 野呂智仁 ${ }^{1)}$, 安形俊久 ${ }^{1)}$, 本多克行 ${ }^{1)}$,

塩田規帆 ${ }^{12}$ ，尾関伸司 ${ }^{11}$ ，遠山邦宏 ${ }^{2}$

(はじめに)肛門失禁はガスと便失禁を含めた失禁で, これまでの報告 は高齢者を対象とした報告が多く $2-24 \%$ とされている. 肛門失禁の 状態を明らかにするために, 若年者を中心にアンケート調査を行った. (対象）排便に関する講演会や講義に出席しアンケートに答えた 329 人（回答率 $95 \%$ ）を対象とした。肛門失禁の有無，出産歴，肛門疾患 の既往，尿失禁の有無，肚門失禁有の場合には頻度や便の性状別の失 禁の有無も問うた. 性別は女性 216 人, 性別不明 4 人で平均年齢は 32.5 歳 (20-91), 学生が $67 \%$, 看護師が $15 \%$ であった. (結果) 肛門失禁が ない例は $70 \%$ で，ガス $25 \%$, 下痢便 $1.5 \%$, 固形便で $0.3 \%$ が失禁で, 女性は男性に比し有意に $(36.2-9.4 \%, \mathrm{p}<0.001)$ 頻度が高かった。頻 度は毎日もしくは週単位の人が $46 \%$ であった. 20 代の肛門失禁の頻 度は $18.5 \%$ で年代とともに頻度が増加し, 70 代では $72 \%$ となり ここの 傾向は女性に特有であった．出産の経験有りの場合の頻度は $63.5 \%$ で 無しの $26.5 \%$ に比し有意 $(\mathrm{p}=0.001)$ に高かったが，年齢を 20-40 歳に 限定すると出産の有無で有意差はなかった. さらに出産の回数と失禁 の頻度の関連はなかった。肛門失禁の既往のある人はない人に比し有 意に肛門失禁の頻度が高かった $(\mathrm{p}<0.011)$ ，尿失禁は $14 \%$ にみられ， 尿失禁のある人の肛門失禁の頻度は $55.6 \%$ で, ない人の $23.2 \%$ に比し 有意 $(\mathrm{p}<0.001)$ 高かった. (まとめ) 若年者でも肛門失禁の頻度は少な くなかった，肚門失禁は女性に多く, 年齢とともに増加し, 出産があ る場合には有意に頻度が高いが, 若年の女性では頻度に差がなかった。 これより出産例では, 晚期に肛門失禁が出現してくる可能性が示唆さ れた。尿失禁も少なからず合併するので，同時に問診し治療の必要が あると考えられた

\section{WS4-3 小児の便失禁の病態と治療}

京都府立医科大学小児外科学

佐々木康成, 津田知樹, 小野 滋, 木村 修, 岩井直躬

【目的】小児の便失禁は, 器質的疾患の有無によって大別される. 器質 的疾患で最も多いものは直腸肛門奇形術後の患児であり，器質的疾患 のない例では便秘を伴った遺粪症が最も多い. 今回, 小児の便失禁に 対する病態と治療について検討し，特に当科で Biofeedback 療法を施 行し良好な排便管理を維持している便失禁症例につき報告する.【方 法】小児便失禁の病態に扔いて, 腹部単純 X 線で便塊貯留や仙骨異常 の有無を確認する。さらに直腸肛門内圧測定で肍門管静止圧や直腸 compliance を計測し, 注腸検査で megarectum や megacolon の有無 を評価し診断する，小児の便失禁の治療はまず浣腸や坐薬による保存 的療法を行うが，良好な排便管理が困難な場合 Biofeedback 療法を行 い良好な排便管理を維持する。便失禁を伴う 30 例の遺糞症および 16 例の直腸肛門奇形術後（高位型 10 例，中間位型 5 例，総排泄腔症 1 例）の患児に本療法を施行した．治療前後の排便機能評価には Kelly score（6 点満点）を用いた.【成績】遺粪症患児では，全例で直腸内に 多量の便塊を認めた。また注腸検査では，著明に拡張した直腸を認め たが，狭小部は認めなかった。直腸肛門内圧測定では，肚門管静止圧 は $53.7 \pm 12.5 \mathrm{cmH}_{2} \mathrm{O}$ で，全例に直腸肛門反射を認めた．直腸 compliance は $4.63 \pm 3.21 \mathrm{ml} / \mathrm{cmH}_{2} \mathrm{O}$ であった．本療法施行前の Kelly score の平均は $3.39 \pm 1.02$ であったが，施行後には 28 例 (93\%) で改善し， score 平均值は $5.43 \pm 0.79$ となった。 また, 肛門管静止圧は $54.2 \pm 11.7$ $\mathrm{cmH}_{2} \mathrm{O}$ で, 直腸 compliance は $3.66 \pm 2.12 \mathrm{ml} / \mathrm{cmH}_{2} \mathrm{O}$ であった。 直腸肛 門奇形術後患児では直腸肛門内圧測定で, 肛門管静止圧は $26.1 \pm 5.2$ $\mathrm{cmH}_{2} \mathrm{O}$, 全症例に直腸肛門反射を認めなかった。直腸 compliance は $4.39 \pm 1.09 \mathrm{ml} / \mathrm{cmH}_{2} \mathrm{O}$ であった。本療法施行前の Kelly score 平均は $2.13 \pm 1.36$ であったが，施行後には 5 例 $(31 \%)$ で改善し, score 平均 值は $2.69 \pm 1.14$ であった【結論】Biofeedback 療法は遺粪症のほとん どの症例において有効であった。また，直腸肛門奇形術後の患児でこ の訓練により便失禁の改善を認める症例は約 $30 \%$ であり,半数の症例 では長期にわたる排便機能の維持に本療法を繰り返し行う必要があっ た。

\section{WS4-4 便失禁患者における Vector volume (3D Manometory) の検討}

藤田保健衛生大学下部消化管外科

野呂智仁，前田耕太郎，花井恒一，佐藤美信，升森宏次，小出欣和， 松岡 宏, 勝野秀稔, 安形俊久, 本多克行, 塩田規帆, 遠山邦宏

[はじめに]便失禁などの機能性疾患は, 詳細な問診と共に様々な機能 検査を行い, 総合的に判断して治療を行う必要がある。機能検査の中 でも直腸肛門内圧検査は, 直腸肛門部の機能検査の中心となる検査で ある。近年，多チャンネルを有するカテーテルが登場し，Vector volume（3D Manometory）を構築することが可能となり，肛門内压を視 覚的に捉えること出来るようになった。しかし，その形態の解析はま だまだ検討されていない，そこで今回我々は，便失禁患者のVector volumeついて検討した. [対象] 2007 年 9 月から 2009 年 4 月までに, $8 \mathrm{ch}$ カテーテルを用いて直腸肛門内圧検査を施行した 100 例. [方法] 8 ch カテーテルと自動引き抜き装置を用いて, 引き抜き検査を施行. 肚 門管最大静止圧を測定し, Vector volume $(\mathrm{mmHg} 2 \mathrm{~cm})$ を測定した. 引き抜き検查は 3 回施行し, その平均值を使用した。対象群をWexner's scoreにより点数別に分類し (A 群 : 0 点 (47 例), B 群 : 1 9 点 (31 例), $C$ 群 : 10 20 点 $(22$ 例)), それぞれの Vector volume について比較検討を行った. A 群 : 平均年齢 61.0 歳, 性差 ; 男 : 女 = $24: 23$, 原疾患：直腸癌 25 例, 直腸脱 8 例, 直腸瘤 4 例, その他, 脊椎 疾患, 炎症性腸疾患等. B 群 : 平均年齢 57.6 歳, 性差; 男 : 女 $=8: 23$, 原疾患：直腸脱 11 例, 直腸癌 7 例, 脊椎疾患 4 例, 直腸瘤 2 例, その 他, 排便障害等. C 群 : 平均年齢 72.3 歳, 性差; 男 : 女 $=4: 18$, 原疾 患：直腸脱 13 例, 直腸癌 3 例, 排便障害 4 例, その他, 直腸瘤等であっ た。統計学的処理は, Mann-Whitney's U 検定を用いて行い, P 值 0.05 以下を有意差ありとした. [結果] A 群に男女差は認めなかった. B， C 群では女性が多かった。C 群は他の 2 群に比べて, 有意に高齢 $(\mathrm{P}=$ $0.001, \mathrm{P}=0.001)$ であった. Vector volumeの平均は, A 群 : 15521.4 $14982.4 \mathrm{mmHg} 2 \mathrm{~cm}$ (Mean \pm SD, 以下同様), B 群 : 8158.4 \pm 6198.9 mmHg2cm, C 群 : $4367.5 \pm 5601.5 \mathrm{mmHg} 2 \mathrm{~cm}$ であった. B 群は A 群に 比し, 有意に低值 $(\mathrm{P}=0.008)$ であり, $\mathrm{C}$ 群は $\mathrm{A}, \mathrm{B}$ 群に比し, 有意に 低值 $(\mathrm{P}=0.011, \mathrm{P}=0.001)$ であった。また，便失禁群の Vector volume では，不整な形が多かった［結語］便失禁患者の Vector volume は， 失禁の無い症例に比べ, 低值であり不整な形が多かった. 


\section{WS4-5 分婏後に発症した便失禁症例の検討}

社会保険中央総合病院大腸肚門病センター

山名哲郎, 積美保子, 法地聡果, 金子由紀, 高橋 聡, 小野朋二郎, 森本幸治, 西尾梨沙, 岡田大介, 古川聡美, 岡本欣也, 佐原力三郎

【目的】便失禁を主訴に外来を受診する患者の多くは高齢者であるが, 分娩後に便失禁症状を発症して受診する 20 代から 40 代の比較的若い 女性も少なくない. 今回我々は分婏後に便失禁を発症した患者の特徵 をあきらかにすることを目的に本研究を行った【対象と方法】 2007 年 1 月より 2009 年 3 月までに便失禁を主訴に受診した患者の中から 分婏後 10 年以内の患者を対象とし，年齢，分婏歴，分娩方法，分婏時 合併症，受診時 Wexner スコア，直腸肛門機能検査，治療やフォロー アップの経過と問題点について，便失禁患者のデータベースと診療記 録を retrospective に検討した.【結果】対象とした期間に分婏後の便失 禁を主訴に受診した患者は 30 人, 年齢は 29 歳から 45 歳 (平均年齢 36 歳)であった。分婏歴は 1 回 20 人, 2 回 10 人であった。分婏方法は全 例が経腔分婏であり, そのうち鉗子分婏 12 人, 吸引分娩 6 人であった. 分婏時合併症としては会陰裂傷を 21 人に認めた。受診時の Wexner スコアは 1 点〜20 点 (平均 11 点) であった．直腸肛門機能検査值では 肛門管最大静止圧が $11 \mathrm{mmHg} \sim 102 \mathrm{mmHg}$ (平均 $41 \mathrm{mmHg}$ ), 最大随意 収縮圧が $24 \mathrm{mmHg} \sim 234 \mathrm{mmHg}$ (平均 $77 \mathrm{mmHg}$ ）であった。肛門管超 音波検査で顕著な外肛門括約筋欠損所見を 12 例に認めた. 陰部神経伝 達遅延速度を測定した 11 人中 4 人で左右片側または両側の遅延を認 めた．治療は 12 人が括約筋形成術（オーバーラップ法）を施行し, 11 人で症状の改善を得た. 残りの 18 人はバイオフィードバック療法また は便性コントロールで症状の改善傾向が見られた。保存的治療を行っ た 18 人のうち 3 人は不安やうつ症状が顕著であり精神的なケアが必 要であった【結語】分婏後の便失禁発症例は初産時の会陰裂傷の合併 例が多いが，あきらかな会院裂傷のない院部神経障害が疑われる症例 も認められた。治療は顕著な外肛門括約筋欠損例では括約筋形成術, 括約筋損傷のないもしくは軽度な症例ではバイオフィードバック療法 や便性コントロールおよび精神的カウンセリングによる保存的治療が 有効であった。

\section{WS4-6 便失禁に対する保存的治療の検討}

\section{くにもと病院肍門科 ${ }^{1)} 〈 に も と$ 病院臨床検查部 2} 安部達也 ${ }^{1)}$, 國本正雄 ${ }^{12}$, 鉢吕芳一 ${ }^{1)}$, 佐藤ゆりか ${ }^{21}$

【目的】便失禁は高齢者に多く良性疾患であるため, 一次治療として保 存的治療が行われることが多い. 今回, 自験例における保存的治療の 成績について検討した.【方法】対象は 2005 年 3 月から 2008 年 12 月の 間に当院の便失禁外来を受診した 404 例のうち, 手術を行った 22 例を 除く 382 例（女 252 例，平均年齢 67 歳）。食事や排便の指導および骨 盤底体操は，一部の認知症患者を除き全例に行った，そのうえで各症 例の病態や患者の希望に添って治療法を選択した。すなわち，軟便や 下痢時のみ漏れる場合にはポリカルボフィルカルシウム (以下 CP) や 止痢剤で便形状を調整し, 溢流性便失禁や慢性の便秘が関与していれ ば下剂による排便コントロールを行った，括約筋不全には，切迫性の 症状が主体で随意収縮圧（MSP）が低下していればバイオフィード バック療法 $(\mathrm{BF})$ を, 漏出性便失禁を主訴とし最大静止圧 (MRP) が 低下していれば，肛門管低周波電気刺激療法（以下，低周波）を行っ た. 重症度判定は Wexner's スコアを用いて, 同スコアが減少したもの を改善, 0 になったものを治瘉とした.【結果】初回治療として行ったの は, $\mathrm{CP}$ 単独 70 例, 低周波単独 138 例, 低周波 $+\mathrm{BF} 37$ 例, BF 単独 8 例, 低周波 $+\mathrm{CP} 12$ 例, $\mathrm{BF}+\mathrm{CP} 4$ 例, 低周波 $+\mathrm{BF}+\mathrm{CP} 5$ 例, 下剂に よる排便コントロール 20 例, 止㾥剤や整腸剤 7 例, 生活アドバイスな どの支援療法のみ 53 例であった。 $\mathrm{CP}$ 単独は, 評価可能できた 50 例の うち 45 例 $(90 \%)$ で改善し，そのうち 15 例 $(30 \%)$ が治瘉した。低 周波単独は，評価できた 107 例中 92 例 (86\%) で改善し，19 例 (18\%) が治癒した。ささに, 肚門内圧は MRP が治療前平均 30 から治療後 37 $\mathrm{mmHg}, \mathrm{MSP}$ も治療前 130 から治療後 $145 \mathrm{mmHg}$ といずれも上昇し た。低周波 $+\mathrm{BF}$ は, 評価可能な 32 例のうち 28 例 (88\%) で改善し, うち 9 例 $(28 \%)$ が治癒した. MRP (治療前 34 から治療後 $37 \mathrm{mmHg}$ ) と MSP（治療前 76 から治療後 $113 \mathrm{mmHg}$ ) もそれぞれ上昇した.【結 語】便失禁はその病態をできるだけ正確に把握して, それに適した保 存的治療を行うことで，その多くが改善し，治癒することも少なくな かった.

\section{WS4-7 高齢者便失禁に対する当医院の対応}

坂田肚門科医院

坂田寛人

何時の間にか便が漏れる，下着が污れる，高齢者では歩行中や排尿時 に便が出て困る便失禁例は, 外来患者の $0.5 \%$ ではあるが, 日常生活に 支障を来たすため問題視している. 痔瘦や会陰切開後, 直腸脱に伴い, 粪便栓塞後, 仙髄領域の帯状疮疹時, IBS, 精神疾患, 脳梗塞後など, その原因は多岐にわたる。平均年齢は 73 才で特発性便失禁が最も多 く，今回は高齢者便失禁に対し検討する. 問診で便意がなく漏れる， 下着が污れる。診察では肛門の開大，括約筋の緊張低下，直腸肛門角 の鈍化などが診断の有力な手掛かりであるが, 便を完全に出しきらな いなどの排便困難も認められる．また，尿漏れ，頻尿や子宮脱・膀胱 脱・会陰下垂も重要な所見である。病状の評価とデー夕を得るため直 腸肛門内圧測定と超音波検査を行なっている。仙骨神経障害を伴う場 合 MRI を行ない，会陰痛を訴える 28 例中 3 例に便失禁を 2 例に排便 困難を認め, これらは椎間板へルニア，春柱管狭窄を伴っていた．治 療は，専ら保存療法に徹している。まず残便対策として，便失禁例に は排便後の肛門洗浄，浣腸の使用を勧めている．有形便では食物繊維 (糠・サイリウムハスク)を投与し, 薬物療法として糞便の固形化を目 的にタンニン酸の投与や抗コリン郕(コリオパン)を投与していたが, 新しい型の抗コリン剂に便失禁抑制効果が報告され, 平成 19〜20 年に 便失禁を主訴に来院した 27 例に対し塩酸プロピベリン $20 \mathrm{mg} /$ 日ある いはイミダフェナシン $0.1 \mathrm{mg} /$ 日を投与し, 結果として 27 例中 11 例に 便失禁の消失を，13 例に減少を，3例に症状不変を認めている。また 局所治療として自家製のネオスチグミン軟膏を使用している。ネオス チグミンは, 加齢により劣化した肚門括約筋の収縮回復に有効と考え, ネオグスチミンを亜鉛華軟膏に溶解し $0.1 \%$ ネオスチグミン軟膏を作 製し, 平成 $16 \sim 17$ 年の便失禁 9 例及び Soiling13 例に対し局所塗布し, 22 例中 17 例に良好との回答を得, 更に肚門管内圧の上昇が認められ, 有効と見做し使用している. 以上当院では便失禁の保存的治療として, 残便対策，コリン作動性ネオスチグミン軟膏の局所塗布及び新しい抗 コリン剤の投与を 3 本柱としている。

\section{WS4-8 肛門括約筋断裂に対する括約筋縫合術施行例の検討}

大腸肛門病センター高野病院

久野三朗, 緒方俊二, 佐伯泰懭, 福永光子, 高野正太, 山田一隆, 高野正博

目的；失禁を伴った括約不全例のうち産道外傷などの実際に括約筋の 断裂を生じた例に対する括約筋縫合術施行例の術前後の肍門機能につ き検討した。対象と方法; 平成 17 年 1 月 1 日より平成 19 年 12 月 31 日までの上記対象者，計 18 例につきカルテ調査により検討した，当院 では活約不全に対しては術前にバイオフィードバック等の保存療法の 後改善が不十分な場合には下記の手術方法を取っている。即ち手術方 法としては脊椎麻酔下に砕石位で断裂部の皮䖉切開を行い㓔痕組織よ り断裂した肛門括約筋の断端を遊離しnon absorbable の monofilament 糸でオーバーラップして埋没縫合を行うものである. 結果 ; 内 訳は男 4 例 $(22 \%)$ 女 14 例 $(78 \%)$ 手術時年令は $58 \pm 15(27$ 83) 才, 原因疾患は出産時外傷 $11(62 \%)$ 肛門疾患術後疑い $3(17 \%)$ 痔瘦術 後 2（11\%）腫瘤切除後 1（5\%）不明 1（5\%）であった。肛門管長は 術前が $36 \pm 7(23 \sim 50) \mathrm{mm}$ 術後が $36 \pm 5(27 \sim 46) \mathrm{mm}$ ，最大静止圧

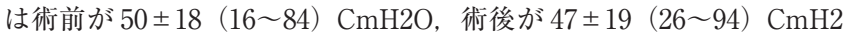
$\mathrm{O}$ 最大随意圧は術前が $152 \pm 85(42 \sim 359) \mathrm{CmH} 2 \mathrm{O}$ 術後が $174 \pm 134$ （49～528） CmH2O でありいずれも術前後で有意差は認めなかったが 最大随意圧は術後に増加傾向を認めた。 また再手術例は無かった。考 察および結語；失禁を伴う肛門括約筋断裂に対する当院の術式による 術後は最大随意圧の上昇傾向を認めとくに切迫性便失禁の改善が得ら れると推測された，今後アンケート調査を行い便失禁の改善の程度や 満足度等も検討する予定である。 


\section{WS5-1＼cjkstart痔瘻治療におけるエビデンス}

所沢肛門病院

栗原浩幸，金井忠男，石川 徹，金井慎一郎，張 文誠，金井亮太

【はじめに】痔瘦治療のエビデンスを求めるには，以下のコンセンサス が不可欠である。すなわち明確な痔瘦分類および術式とその内容の統 一である. 昨年我々は後方複雑痔瘦および低位筋間痔瘦を明確化した 痔瘦分類についての論文を発表し，それにより曖昧であった痔瘦を明 確に分類できるようになった，今回は我々が行っている術式とその内 容を明確化し，それらを適応した治療成績を述べる.【術式】低位筋間 痔瘦： lay open と coring out に分ける. 原則は lay open であるが, 2 次口が肛門縁より $2 \mathrm{~cm}$ 以上離れている時には coring out を行う。 Lay open には fistulotomy と fistulectomy とがある. Fistulotomy でも瘦管 壁の $2 / 3$ は切除する. Coring out は, 瘦管貫通部の外括約筋はくりぬく が内括約部は fistulotomy する coring lay open や, 内外括約筋部すべ てくりぬく complete coring out を行う.いずれも 2 次口側から瘦管を 追跡し 1 次口を確実に同定する. 高位筋間痔瘦：低位筋間痔瘦を合併 している場合にはその部分を，していない場合には原発口より手前側 の内括約筋を lay open するように切離する. 高位の部分は内括約筋を 温存し可及的に切除する。坐骨直腸窩痔瘦：病態に基づき原発巣であ る後方深部痔瘦をまず開放し, 1 次瘦管と原発口を直視下に開放する. 坐骨直腸窩の 2 次瘦管については適宜切除または掻破を行う。成績】 2004 5 年に同一術者が行った痔瘦手術例は 264 例で，低位筋間痔瘦 204 例，高位筋間痔瘦 15 例，坐骨直腸窩痔瘦 45 例（3P or Courtney 10 例, 3H or 3L35 例)であった。低位筋間痔瘦の $68 \%$ は lay open, 残 りは coring lay open を行い, 高位筋間痔㾇, 坐骨直腸窩痔㾇について は全例上述の方法を行った。術後機能障害は認めなかった。各痔瘦分 類の入院期間（日）, 治癒期間（日）, 再発率を以下に示す。低位筋間 痔瘦 : $7.7 \pm 1.7,40.3 \pm 26.1,3 / 203(1.5 \%)$. 高位筋間痔瘦 : $7.9 \pm 0.6$, $36.3 \pm 16.7,1 / 15(6.7 \%)$. 坐骨直腸窩痔瘦 : $9.5 \pm 2.0,78.3 \pm 53.3,0 / 30$ $(0 \%)$. (3P or Courtney : $9.3 \pm 1.2,54.3 \pm 36.5,0 / 8(0 \%)$, $3 \mathrm{H}$ or L : $9.6 \pm$ $2.2,87.0 \pm 56.4,0 / 22(0 \%))$.【結語】当院の痔瘦手術は再発率・術後合 併症も少なく，ほほ確立した術式と考える。

WS5-2 当院の痔瘦に対する術式選択と術手技の再発および合併症 からみた成績の検討一再発および合併症の定義の検討一

大腸肛門病センター高野病院

高野正太, 緒方俊二, 佐伯泰愼, 福永光子, 田中正文, 眞方紳一郎, 坂田玄太郎, 久野三朗, 中村 寧, 山田一隆, 高野正博

【はじめに】当院では過去における肚門内圧などの検討から次のような 結果を得ている. 1. 前方側方低位筋間痔瘦 (IIL) では開放術を行うと 術後肛門の静止圧, 随意圧ともに回復の度合いが少ない. 2. seton 法に 対する比較においても括約筋温存術は静止圧の低下が有意に少ない. 3. 深部痔瘦においては Hanley 法と比較し括約筋温存術の方が肛門内 圧の低下が少ない，そこで当院では隅越分類に基づき診断した後，高 位筋間痔瘦 (IIH), 後方 IIL に対しては開放術, 前方側方 IIL, 坐骨直 腸窩痔瘦 (III), 骨盤直腸窩痔㾇 (IV) に対しては括約筋温存術を基本 術式としている。 今回は術後経過を短期的な合併症を含め検討し，当 院における術式選択および術手技の妥当性を検証した.【対象】 2003 年 4 月から 2005 年 3 月の当院での痔瘦手術 492 例中, クローン病合併 症例を除外した 438 例.【方法と結果】男性 : 女性 $381: 57$, 平均年齢 $41.5 \pm 11.2$ 歳. 平均術後在院日数 IIL $12.8 \pm 3.9$ 日, IIH14.5 \pm 7.6 日, III $16.8 \pm 6.1$ 日, IV $22.1 \pm 8.2$ 日. 平均治瘾期間 IIL $54.2 \pm 42.1$ 日, IIH $80.5 \pm$ 71.6 日, III97. $4 \pm 61.6$ 日, IV111.5 \pm 66.3 日. 開放術において術後一次口 を再形成するように上皮が再生され排膿が続く症例を再発とした。括 約筋温存術では一旦閉鎖した一次口が再開通し排膿が続く症例を再発 とし，術後閉鎖を認めない状態で開通した場合は不治癒とした，再発 率は IIL4.1\%, IIH3.2\%, III5.9\%, IV8.2\% であった. 合併症はスコア 2 以上の疼痛, 処置を要した後出血, ガスおよび便漏れとし, 合併症率 は IIL 27.5\%，IIH25.1\%，III31.2\%，IV25.7\% であった.【考察】今回は 術後短期的な侵襲を含め長期術後経過を検討した．当院における痔瘦 の再発率は全体で $4.9 \%$ であり術式選択，手技は妥当であると考えら れた．現在，再発および合併症の定義は定まっておらず検討がなされ ている段階と思われる. 今後定義に基づいた論議が必要と考えられ, 今回は当院における定義を明示しガイドラインにつながる検討を行 j.

\section{WS5-3 エビデンスにもとづく痔瘻治療の検討}

松島病院大腸肛門病センター

田中良明, 松島 誠, 伊東 功, 杉田博俊, 香取玲美, 辺見英之, 森岡 香, 完山裕基, 宋 江楓, 松村奈緒美, 下島裕寛,

長谷川信吾, 岡本康介, 鈴木 裕, 鈴木和徳

【はじめに】痔瘦根治手術においてはその根治性と直腸肛門部の形態 · 機能の温存が重要である. そのためには 1 . 正確な病型と詳細な病態を 含む瘅㾇の質的な診断 2. 原発口 原発巣の確実な処置 3. 原発巣処置 部への修復法の選択が必要となる。当院では【リニア式経肛門的超音 波検査を中心とした術前評価（田中の分類など）】および【術中での判 断基準】にしたがい症例の重症度や病態の違いに適した各術式を選択 している.これらを考慮した痔瘦治療について報告する.【目的】当院 の痔瘦手術施行例に対して詳細な検討を行い，エビデンスにもとづい た痔㾇治療におけるポイントやリスクファクターなどを検討する.【対 象・方法】特定の術者 1 人による 5 年間 $(2003$ 年 1 月 2007 年 12 月) の瘅瘦手術施行例を対象とし以下について検討した。 術前 : 病悩期 間・切開排膿などの既往歴，排便習慣，体型や殿裂の深さ，肛門管の 解剖学的形態, 超音波検査を中心とした痔瘦の病型および詳細な病態 など，術中：術前の予定術式と実際に施行された術式との関係，手術 時間など, 術後：術後の排便や疼痛の状態，入院および治癒期間，再 発（いわゆる再開通）や治癒遷延とその対応など.【結果】おもな結果 は以下であった 1.5 年間の痔瘦根治手術施行計 885 例（当院の全痔瘦 根治手術 5520 例の $16.0 \%$ ）2. 各病型の再発率 (各病型の再発例/総数) IILs $0.7 \%(4 / 547)$, IILc $0.0 \%(0 / 71)$, IIHs $0.0 \%(0 / 43)$, IIHc0.0\% (0/ 62), III $3.3 \%(3 / 91), \quad$ III $_{B} 3.1 \%(2 / 64)$ ，IV12.5\%（1/8）3. 再発した 術式の結果（各病型における各術式の再発例/総施行例）・ IILs 瘦管切 除＋創部縫縮 1.1\%(2/177), 隅越式 1.2\% (2/165) - IIIU 筋縫合術 $2.8 \%$ $(2 / 71)$, 筋充填術 $6.3 \%(1 / 16) \cdot$ III $_{B}$ 筋縫合術 $2.3 \%(1 / 44)$, 筋充填 術 $10.0 \%(1 / 10) \cdot$ IV 筋充填術 $12.5 \%$ (1/8)【考察】以下の点を検討す る. 1. 痔瘦治療上大きな影響を与えると思われる因子, とくに再発痔 瘦に関する「超音波検査上の特徴」など 2 . 病型と各術式の成績からみ たその問題点・改良点 3. 他【おわりに】今回のエビデンスにもとづく 検討を侵襲や再発のより少ない術式や術後肛門の将来までも熟慮した 治療法の確立につなげたい

\section{WS5-4 痔瘻術後の治癒と治癒不良・再開通，再発}

大腸肛門病センター高野会くるめ病院 ${ }^{1)}$, 久留米大学外科 ${ }^{2)}$ 野明俊裕 ${ }^{1}$, 荒木靖三 ${ }^{11}$, 中川元典 ${ }^{1)}$, 鍋山健太郎 ${ }^{12}$, 岩谷泰江 ${ }^{11}$, 小篠洋之 ${ }^{11}$, 高野正博 ${ }^{1)}$, 白水和雄 ${ }^{2}$

【背景】痔瘦の治療は手術が基本であるが, 確実な治療と合併症予防の ためには肛門の解剖を熟知し, 痔㾇の形態を把握する必要がある。当 院では隅越の分類により痔㾇の基本術式を決め, できる限り定型化し た手術を行うようにしている。皮下痔瘦 (I 型) および後方低位筋間痔 瘦 (IIL 型) は瘦管開放術, 前側方 IIL 型は㾇管くり抜き切除（括約筋 温存手術), 高位筋間痔瘦は必要に応じて seton 法を追加する。坐骨直 腸窩痔瘦（III 型）・骨盤直腸窩痔㾇（IV 型）は括約筋温存手術で原発 口切除，閉鎖と括約筋外原発膿瘍腔ドレナージを標準術式として行っ ている.【目的】痔瘦の術式別の治痛期間, 治癒不良・再開通, 再発症 例を明らかにし，その問題点を検討する.【対象・方法】 2002 年 4 月か ら 2008 年 1 月までの当院で IBD を除く痔瘦の手術は 982 例, 年齢は $41.7 \pm 19.9$ 歳, 男女比は $866: 116$ 名と男性に多く, 隅越の分類による病 型は I 型 57 例 $(5.8 \%)$, II 型 716 例 $(72.3 \%)$, III 型 159 例 $(15.3 \%)$, IV 型 63 例 $(6.0 \%)$ であった。肛門管からドレナージ創まで完全に瘏 痕化した時点で治㾑と判定した。それが確認された後の同部位に痔瘦 を認めたものを再発とし, 治癒確認なく痔瘦を認めたものは治癒不 良・再開通とした.【結果】平均治癒期間は, II 型の前側方のくり抜き 法では $84.5 \pm 67.3$ 日 $(12-375$ 日), 瘦管開放術では $101 \pm 90.4$ 日 $(28$ -415 日), seton 法では $167 \pm 251$ 日 $(26-732$ 日). 再発は 56 例 $(5.7 \%)$ に認められ, 病型別ではI型 2 例 $(3.5 \%)$, II 型 30 例 $(4.2 \%)$, III 型 8 例 $(12.6 \%)$, IV 型 5 例 $(8.5 \%)$ と III 型に再発が多く認められた. II 型の術式別では前側方のくり抜き法では 208 例中 16 例 $(7.7 \%)$, 後 方の瘦管開放術では 397 例中 9 例 $(2.3 \%)$, seton 法を用いた場合では 26 例中 5 例 (19.2\%) の治癒不良, 再発例を認めた.【考察】 現在の所, どの病型，術式も再発，治㾑不良・再開通率 $0 \%$ は達成でできていな い. 手術の習熟度をあげ，㾇管の走行診断を確実にすることでより再 発率を下げる努力が必要と考えられた。 


\section{WS5-5 当院における痔瘻の治療成績}

鮫島病院外科 ${ }^{11}$, 鮫島病院内科 ${ }^{21}$

鮫島隆志 ${ }^{11}$, 丹羽清志 ${ }^{1)}$, 江藤忠明 ${ }^{11}$, 鮫島加奈子 ${ }^{11}$, 鮫島 潤 ${ }^{11}$,

鮫島由規則 ${ }^{2}$, 今村芳郎 ${ }^{22}$, 平川あさみ

【はじめに】当院では隅越分類に沿って痔㾇を分類し術式を決定してい る.すなわち, I 型は seton または開放術, II 型は開放術, III 型は Hanlay 変法, IV 型には開放術に drainage を組み合わせる手技を基本とし ている。これらの手術成績を顧みた.【対象と検討項目】過去 5 年間に 手術が行われた痔瘦単独症例 1183 例（男性 896 例，女性 287 例）を対 象にした。隅越分類では I 88 例, II 899 例, III 183 例, IV 13 例である. 初回手術成績として, 入院日数, 治癒期間, 合併症, 再発率を調査し, 再発例に対する処置およびその成績を検討した.【結果・考察】入院日 数は I II III IV 型の順にそれぞれ，平均 5.2 日，10.4 日，13.8 日，25.7 日であった，治癒を創がほほ上皮化し治療を要しないまで，とした治 癒期間はそれぞれ，平均 24.8 日，22.3 日，27.2 日，40.4 日であった。 合併症は II 型に 4 例，III 型に 3 例，IV 型に 1 例出血が，また IV 型の 1 例に一過性の漏便がみられた。再発はそれぞれ，2例 $(2.3 \%), 18$ 例 $(2.0 \%), 8$ 例 $(4.4 \%), 2$ 例 $(15.4 \%)$ であった. I 型の 2 例は seton を行った症例で， 3 ヶ月以内に再発し，再処置は開放術を行ったＩI 型では 3 例が一次孔残存で, 術後 6 ケ月, 12 ケ月, 14 ケ月の再発であっ た。他は創皮下の死腔への膿瘍形成で全例 6 ヶ月以内に発症した。一 次孔残存例は再度開放術を, その他は創開放で治癒した. III 型は全例 drainage 部の再燃で, 膿瘍腔掻爬と再 drainage を行った. IV 型は 2 例とも高位直腸瘦を形成しており, 3 ケ月以内の再発で, 難治であった ため一時的人工肛門を造設して管理した【結語】痔瘦治療において, III 型までは入院期間，治癒期間に差はなく，治療成績は良好である。 再発は一次孔残存によるものは少なく, 創皮下や drainage 不良による もので, 改善の余地がある. IV 型は術創が深くなるために入院期間, 治癒期間が長期化した。 また, 早期に再発を認めたものは直腸瘦の存 在を疑い観察，処置を行うことが肝要である。

\section{WS5-6 当院で行われている痔瘻に対する標準術式と成績}

四日市社会保険病院外科大腸肛門病 IBD センター 梅枝 覚, 松本好市, 北川達士, 野地みどり, 山本隆行, 石井雅昭, 肥満智紀, 山崎 学

当院では，痔㿉に対する治療方針としては，原発口（肚門小窩）と原 発巣を含む二次口までの全瘦管の切除をスタンダードの手術としてい る. 平成 4 年から平成 20 年 12 月までに当院で根治手術を行った痔瘦 の症例は 1520 例であった. 痔瘦の分類は隅越分類を用いており, 痔瘦 1 型 17 例 $(1.12 \%)$, 痔瘦 $2 \mathrm{~L}$ 型 1093 例 $(71.91 \%)$. 痔瘦 $2 \mathrm{~L}+2 \mathrm{H}$ 型 56 例 $(3.68 \%)$, 痔瘦 $2 \mathrm{H}$ 型 33 例 $(2.17 \%)$, 痔瘦 3 型 282 例 $(18.55 \%)$, 痔瘦 4 型 39 例 $(2.57 \%)$ であった。当院の痔瘻根治手術としては, 1 型の痔瘦には全瘦管切除と開放術式を施行, 痔瘦 $2 \mathrm{~L}$ 型後方に対して は原則として原発口（肚門小㸗）と原発巣の切除，二次口へと向かう 瘦管は全瘦管切除と開放術式を施行している。痔㾞 $2 \mathrm{~L}$ 型前方または 側方に向かう㿉管においても, 㿉管の浅い症例に対しては同様の全㾇 管切除と開放術式を施行，前方または側方に向かう㾇管で，㾇管の深 いもの，あるいは全瘦管を開放した場合に括約筋の損傷が大きくなる と思われる症例には，瘦管をくりぬき，括約筋温存手術を施行のうえ， ドレーンまたはシートンを留置している. 痔瘦 3 型に対しては, 原則 として Hanley 変法を行っており, 全瘦管の切除と開放術式を基本と している. 痔瘦 3 型および 4 型に対して, 一期的な手術により括約筋 の損傷や肛門の変形が大きくなると思われる場合はシートンなどで庤 瘦の単純化を行った後に, 時間をおいて痔瘦根治術を行っている。 回, 当院における, 痔瘦の術後経過について最長 15 年から最短 1 年の 追跡にてカルテより調査した。 1 型は 17 例で再発 0\%, 2L 型は 1093 例で再発は 18 例 $1.65 \%, 2 \mathrm{~L}+2 \mathrm{H}$ 型は 56 例で再発は 2 例 $3.57 \%, 2 \mathrm{H}$ 型は 33 例で再発は 1 例 3.03\%, 3 型は 282 例で再発は 5 例 $1.77 \%, 4$ 型は 39 例で再発は 2 例 $5.12 \%$ であった。 また術後に強い肛門機能障 害をきたした症例はみられなかった。結語 : 㾌瘦に対して, 原発口(肚 門小窩）と原発巣の切除, 二次口へと向かう全㾇管を切除する当院が 行っている手術方法は再発率がきわめて少なく，また強い肛門機能障 害もみられず, 痔㿉のスタンダード手術となりうるものと思われた。

\section{WS5-7＼cjkstart当院における痔瘦の手術術式と治療成績}

家田病院

宮田美智也, 家田浩男, 辻 順行, 川瀬恭平, 太田章比古, 赤川高志, 森 俊治

当院の痔瘦に対する治療方針・術式は以下の通りである.【治療方針】 膿瘍期の治療の原則は切開排膿と抗生剤の使用である。切開排膿のよ り膿瘍の硬結が小さく浅くなり, 㿉管が鮮明となりうる。我々は, 瘦 管を形成した痔㾞は再発すると考えており，できる限り炎症の落ち着 いた状態で根治術を施行している。手術の基本は原発口・原発巣・瘦 管の完全開放, 或いは切除である。しかし極端な肛門の変形や過度の 機能障害は避けなくてはならない。 その際は括約筋温存術が選択され るが再開通により再発したり, さらに再手術においては肚門機能はよ り劣ったものになる場合がある。当院では再発や再手術に対する患者 側からの抵抗感は大きく，手術に際してはまず根治性を念頭に置き， その上で可及的に機能温存を図るように考えている.【手術術式】1. IIL 型に対しては, 基本的には fistulotomy, 或いは fistulectomy + 半閉鎖 術式を施行するが，前方や側方で括約筋の損傷が大きくなる一部の症 例には coring outによる括約筋温存術を選択している. 2. IIH 型に対 しては, 原発口・原発巣を切除ドレナージの後, 高位筋間へ進展した 瘦管は可及的に切除するが, その走行上歯状線より口側の括約筋を損 傷し易いので，その際は择爬に止め全切除には固執しない. 3. III 型に 対しては, 炎症が強く瘦管形成が不十分であったり, 術後再発例など のように瘦管や硬結が異常に太く, coring out 困難な場合は Hanley 変法を行うが, 基本は coring outによる可及的㾞管切除, 括約筋温存 である. 4. IV 型に対しては III 型と同様に対処するが, 尾骨切除が必要 となる場合もある。また温存術の際, 骨盤直腸窩へのアプローチが不 十分な場合は, 肛門後方の皮下外括約筋外側より至るドレナージ創を 追加する.【対象】当院における 2000 年 1 月から 2004 年 12 月までの統 計をみると全肚門疾患手術数 9464 例中, 序瘦手術は 2405 例であった. 今回, その内同一術者による痔瘦症例 452 例 (後方 IIL 型 253 例, 前. 側方 IIL 型 104 例, IIH 型 40 例, III 型 41 例, IV 型 14 例 - 痔瘦の複数 存在する症例は, より深部の方に含めた）を対象とし，術式選択と治 療成績について報告する.

\section{WS5-8 前側方の低位筋間痔㾞の治療：seton 法と括約筋温存術の術 後機能と満足度を比較する}

辻仲病院柏の葉大腸肛門病センター ${ }^{1)}$, 東葛辻仲病院 ${ }^{22}$ 赤木一成 ${ }^{1)}$, 辻仲康伸 ${ }^{1}$, 浜畑幸弘 ${ }^{1)}$, 松尾恵五 ${ }^{2}$, 堤 修 ${ }^{1)}$, 中島康雄 ${ }^{2}$, 高瀬康雄 ${ }^{2}$, 新井健広 ${ }^{1)}$, 指山浩志 ${ }^{1)}$, 星野敏彦1), 田澤章宏 ${ }^{2}$, 南有紀子 ${ }^{1)}$, 角田祥之 ${ }^{1)}$, 北山大祐 ${ }^{1}$

【目的】近年われわれの施設では，前側方の低位筋間痔㾇に対し seton 法を行う症例が増加してきている. seton 法は括約筋温存術と比べる と, ・再発率が低い・手技にさほど熟練を要しない・瘦管形成の不十 分な膿瘍期の痔瘦にも対応できる・日帰り手術や短期入院手術にも対 処しやすいなどといった多くの長所がある。一方 seton 法は括約筋温 存術と比較すると術後機能や満足度が劣るとする意見があるが，この 意見を十分な症例数で検討し客観的に裏付けた報告は存在しないと思 われる. 今回の検討では, 前側方の低位筋間痔瘦に対して seton 法また は括約筋温存術にて治療を行った症例にアンケート調查を行い，両術 式間の術後機能および満足度の比較を行った.【対象】東暮辻仲病院で seton 法または括約筋温存術を行った前側方低位筋間痔瘦の症例に対 し，術後 6 ケ月目にアンケートを送付し，回答を得られた 534 例につ いて検討を行った。痔瘦手術の既往がある症例, 複数の痔瘦が存在す る症例, 再発し再手術を要した症例, クローン病を伴う症例は今回の 検討から除外した。術後括約筋機能を Wexner incontinence score (120）にて数值化し, Mann-Whitney U testにて解析を行った. さらに 満足度を 1〜10の 10 段階にスケール化し，同様の解析を行った。結 果】seton 法では 257 例, 括約筋温存術では 277 例から回答が得られ た. 解析の結果, seton 法と括約筋温存術の両群の間には, incontinence score および満足度に有意な差は認められなかった.【結語】われわれ はかつて 2004 年の大腸肛門病学会総会にて, seton 法と括約筋温存術 における術後機能の比較を報告している. 当時の 203 例の検討では, seton 法と括約筋温存術の間に明らかな術後機能および満足度の差は 認められていなかった. 今回の検討では 534 例まで症例数を増やして 比較したにもかかわらず，前回と同様に seton 法と括約筋温存術の間 に術後機能および満足度の差は認められなかった。 
WS5-9 前・側方低位筋間痔瘻に対する新しい術式とその理論一肛門 上皮温存・内括約筋切開・肛門管外ドレナージシートンー

社会保険中央総合病院大腸肛門病センター

佐原力三郎, 法地聡果, 金子由紀, 高橋 聡, 黒木ゆり, 小野朋二郎, 森本幸治, 西尾梨沙, 岡田大介, 古川聡美, 岡本欣也, 山名哲郎

痔瘦発生機序として crypt-glandular infection の考え方は広くコンセ ンサスが得られている. cryptが原発口, anal gland が原発巣でありこ れが痔瘦発生の主要構成要素であるならば, これらを切除する全㾇管 くりぬき術は術式の中で一番理に適っているはずである。しかし実際 にはこの術式の再発率は高く, 各術者が修正・工夫を重ねているのが 現状である.一方, 開放術式の根治性は多くが認めるものの, 肛門への 過剩な侵襲が懸念されるため, 痔㿉の型, 部位, 患者背景などによって 適応が限定されている. そこで我々は, 開放術式の, どの部分が痔㾇の 根治性にとって必要であり, どの部分が過剩な侵襲となるのか, その点 をもう一度検討しなおすこととした. 検討対象は, 2008 年一年間におけ る同一術者による低位筋間痔瘦手術 128 例とした。後方の低位筋間痔 㾇及び, 前・側方でも浅く短い低位筋間痔癭に対しては開放術式を選 択し，成績良好（67 例中再手術 0 例）であった。平均治癒期間は 2.4 ケ月（最短 1 ケ月〜最長 8 ケ月)であった。一方, 2008 年 3 月から前・ 側方低位筋間痔瘦に対して, 新しい括約筋温存術式(肛門上皮温存 · 内 括約筋切開・肛門管外ドレナージシートン)を選択してきた。 これは, 【1】歯状線外側の内括約筋の硬化あるいは過剩な緊張によって, 原発口 から瘦管を介して原発巣に污物が進入しやすくなるのではないか, 【2】原発巣より外側の瘦管の処理は, 感染巣の除去と持続的なドレナー ジをすれば足りるであろう，という二つの考え方から辿りついた術式 である. 肚門縁からの操作のみで処理できるため, 結果的に crypt 入口 部を含めた肛門上皮は温存可能であり，便による創污染のリスクと術 後創痛が軽減できた。 30 例に施行し，平均治癒期間 2.8 ケ月（最短 2 ケ月〜最長 5 ケ月), 再手術 1 例, 術後 1 週間で退院, 3 週間で日常生活 全面復帰が可能であり, 肛門変形や機能面でも問題なく, 後方低位筋間 痔瘦に対する開放術式と遜色のない良好な成績を得た。痔瘦治療にお けるエビデンスの中で, 原発口の考え方と痔㾇発生の背景を再考慮す る必要性を示唆する結果であると思われた。

\section{WS5-10 MRI navigating seton 手術とその術後経過}

\section{音羽病院大腸肛門科}

加川隆三郎, 野村英明

【はじめに】 MRI navigating seton 手術とは, ジャックナイフ位 MRI 法で痔瘦を $3 \mathrm{D}$ 解析, 原発巣膿瘍にピンポイントでいたり, ここから最 短の距離, 最小の組織量で, 原発口へ seton 手術をおこなう術式であ る. 残る膿瘍, 㾇管はドレナージのみをおこなう. 今回, この術式の 術後経過を検討した。なお, 深部痔瘦の「治㾑」とは, 「肉眼的治瘉確 認後, 3 ケ月以上たってからの肛門部 MRI 検査で, 術前に存在したす べての膿瘍, 瘦管の瘢痕化を認めたもの」と定義した。

【症例】平成 18 年 4 月から 21 年 3 月までの 3 年間に洛和会音羽病院で おこなわれた媣部痔瘦 85 例（坐骨直腸䆚痔瘦 77 例，骨盤直腸窩痔瘦 8 例）のうち，炎症性腸疾患をのぞく術後 6 ケ月以上経過した 58 例に ついて検討した。なお 85 例全例が手術翌日に退院した。

【結果】 58 例（男性 49 例，女性 9 例）中, 53 例で治癒を認め, 残る 5 例が術後 6 ケ月以上たっても治療中であった。同一術者（加川）の症 例 32 例では 29 例で治癒を認めた。これら治癒した症例の肉眼的治癒 確認までの日数は, $129.3 \pm 9.7$ 日（mean \pm S.E., 以下同じ）, 最高 244 日であった。肉眼的治癒が確認された患者は全例, その後の MRI 検査 で治癒が確認された. setonのゴム輪の締め直しの回数は, $3.3 \pm 0.3$ 回, 最高 9 回であった. setonの締め直し以外の何らかの処置を要した のは 5 症例で, ゴム輪脱落後に形成された難治創に対する seton 再挿 入が 4 例, 原発口は処理されたが膿瘍腔が遺残, その開放手術をおこ なったものが 3 例, 遺残膿瘍腔に対するフィブリン糊注入が 2 例で あった(重複例を含む). 術後 6 ケ月以上たってもいまだに治瘉を認め ない 3 例は, 肛門挙筋間の遺残膿瘍腔の経過観察中が 1 例（手術を拒 否), 遺残膿瘍腔の開放手術後 (ともに術後 1 ケ月未満) が 2 例であっ た. 平成 21 年 5 月時点で, 「治癒」と判断された 53 例の症例の再発は 認めていない.

ジャックナイフ位 MRI 法では, ミリ単位まで正確な深部痔瘦の立体構 築の解析が可能である。 この解析に基づく MRI navigating seton 手術 は，患者に対する侵襲が極めて小さく，また再発も認めない。現在の 診断技術に基づいた最も論理的な手術と考えられる。 